\title{
Mannose-Specific Lectins from Marine Algae: Diverse Structural Scaffolds Associated to Common Virucidal and Anti-Cancer Properties
}

\author{
Annick Barre ${ }^{1}$, Mathias Simplicien ${ }^{1}$, Hervé Benoist ${ }^{1}$, Els J.M. Van Damme ${ }^{2}$ D \\ and Pierre Rougé ${ }^{1, *}$ \\ 1 Institut de Recherche et Développement, Faculté de Pharmacie, UMR 152 PharmaDev, Université Paul \\ Sabatier, 35 Chemin des Maraîchers, 31062 Toulouse, France \\ 2 Department of Biotechnology, Faculty of Bioscience Engineering, Ghent University, Coupure links 653, \\ B-9000 Ghent, Belgium \\ * Correspondence: pierre.rouge.perso@gmail.com; Tel.: +33-069-552-0851
}

Received: 1 July 2019; Accepted: 24 July 2019; Published: 26 July 2019

\begin{abstract}
To date, a number of mannose-specific lectins have been isolated and characterized from seaweeds, especially from red algae. In fact, man-specific seaweed lectins consist of different structural scaffolds harboring a single or a few carbohydrate-binding sites which specifically recognize mannose-containing glycans. Depending on the structural scaffold, man-specific seaweed lectins belong to five distinct structurally-related lectin families, namely (1) the griffithsin lectin family ( $\beta$-prism I scaffold); (2) the Oscillatoria agardhii agglutinin homolog (OAAH) lectin family ( $\beta$-barrel scaffold); (3) the legume lectin-like lectin family ( $\beta$-sandwich scaffold); (4) the Galanthus nivalis agglutinin (GNA)-like lectin family ( $\beta$-prism II scaffold); and, (5) the MFP2-like lectin family (MFP2-like scaffold). Another algal lectin from Ulva pertusa, has been inferred to the methanol dehydrogenase related lectin family, because it displays a rather different GlcNAc-specificity. In spite of these structural discrepancies, all members from the five lectin families share a common ability to specifically recognize man-containing glycans and, especially, high-mannose type glycans. Because of their mannose-binding specificity, these lectins have been used as valuable tools for deciphering and characterizing the complex mannose-containing glycans from the glycocalyx covering both normal and transformed cells, and as diagnostic tools and therapeutic drugs that specifically recognize the altered high-mannose $\mathrm{N}$-glycans occurring at the surface of various cancer cells. In addition to these anti-cancer properties, man-specific seaweed lectins have been widely used as potent human immunodeficiency virus (HIV-1)-inactivating proteins, due to their capacity to specifically interact with the envelope glycoprotein gp120 and prevent the virion infectivity of HIV-1 towards the host CD4+ T-lymphocyte cells in vitro.
\end{abstract}

Keywords: lectin; seaweed; red algae; mannose-binding specificity; structure-function relationships; diagnostic tool; therapeutic drugs; anti-cancer properties; anti-HIV-1 properties

\section{Introduction}

Lectins have been identified as sugar-binding proteins, in all groups of living organisms including plants, animals, fungi and bacteria, and even in viruses and mycoplasms. Depending on their broad sugar-binding specificity, they have been classified as mannose-, galactose-, $\mathrm{N}$-acetyl-glucosamine-, fucose- and sialic acid-binding lectins, according to the simple sugars that inhibit their carbohydrate-binding properties. In fact, only a few lectins are not inhibited by simple sugars since they only recognize complex glycan chains [1]. Another classification system of lectins in 
twelve different families is based on the structural organization of the lectin domains, irrespective of their sugar-binding specificities [2].

Compared to other plant and animal man-specific lectins, not much attention has been paid to man-specific seaweed lectins, with the exception of griffithsin, a man-specific lectin isolated from the red alga Griffithsia sp. [3], owing to its outstanding anti-human immunodeficiency virus (HIV) properties. Like other man-specific lectins, griffithsin specifically recognize some of the high-mannose $\mathrm{N}$-glycans exposed at the surface of gp120, thus interfering with the recognition of gp120 by the CD4+ T lymphocytes. In fact, the association of three gp120-gp41 tandems forms the HIV-1-envelope spike, which facilitates HIV-1 entry into cells. The Env spike of HIV-1 consists of a transmembrane trimer of gp41 associated to an extracellular trimer of gp120, offering exposed high-mannose glycans to the CD4 recognition process (see Section 6.1). In addition to griffithsin, other man-specific lectins belonging to different groups of algae including Rhodophyta (red algae), Pheophyceae (brown algae), Xanthophyceae (yellow-green algae), and Chlorophyta (green algae), have been identified and characterized, particularly with respect to their anti-HIV properties [4,5]. In addition to their affinity for high-mannose glycans, both cloning and structural information have become available for a few seaweed lectins.

The present review presents an exhaustive overview on the structure-function relationships of man-specific lectins from seaweeds, particularly in relation with their potential biomedical applications as anti-HIV and anticancer agents.

\section{Diversity of Mannose-Binding Lectins in Seaweeds}

Mannose-specific lectins have been identified in almost all the different families of higher plants belonging to monocot and dicot groups [6]. In addition to higher plant lectins, other man-specific lectins were found in lower plant species, algae and mushrooms [7]. To date, however, a still discrete number of alga species were successfully investigated with the aim of identifying and characterizing man-specific lectins, susceptible to be used as relevant biomarkers for HIV gp120 and cancer high-mannose glycoforms. In this respect, red algae or Rhodophyta, appear as the most promising source for man-specific lectins (Table 1).

Table 1. Overview of algal lectins with a mannose-specificity. OAAH- Oscillatoria agardhii agglutinin homolog; GNA—Galanthus nivalis agglutinin.

\begin{tabular}{|c|c|c|c|c|c|}
\hline Algae Phylum & Algae Family & Algae Species & Lectin & $\begin{array}{c}\text { Structural } \\
\text { Scaffold }\end{array}$ & Ref. \\
\hline Red algae & Griffithsin & Griffithsia sp. & griffithsin & $\beta$-prism I & {$[3]$} \\
\hline \multirow{18}{*}{ Brown algae } & \multirow{18}{*}{ OAAH-like } & \multirow{2}{*}{ Agardhiella subulata } & ASL-1, & $\beta$-barrel & \multirow{2}{*}{ [8] } \\
\hline & & & ASL-2 & $\beta$-barrel & \\
\hline & & \multirow{3}{*}{ Eucheuma amakusaensis } & EAA-1 & $\beta$-barrel & \multirow{3}{*}{ [9] } \\
\hline & & & EAA-2 & $\beta$-barrel & \\
\hline & & & EAA-3 & $\beta$-barrel & \\
\hline & & \multirow{2}{*}{ Eucheuma cottonii } & ECA-1 & $\beta$-barrel & \multirow{2}{*}{ [9] } \\
\hline & & & ECA-2 & $\beta$-barrel & \\
\hline & & \multirow{2}{*}{ Eucheuma denticulatum } & EDA-1 & $\beta$-barrel & \multirow{2}{*}{ [10] } \\
\hline & & & EDA-2 & $\beta$-barrel & \\
\hline & & \multirow{2}{*}{ Eucheuma serra } & ESA-1 & $\beta$-barrel & \multirow{2}{*}[11,12]{} \\
\hline & & & ESA-2 & $\beta$-barrel & \\
\hline & & Kappaphycus alvarezii & KAA-2 & $\beta$-barrel & [13] \\
\hline & & Kappaphycus striatum & KSA-2 & $\beta$-barrel & [14] \\
\hline & & Meristiella echinocarpa & MEL & $\beta$-barrel & [8] \\
\hline & & \multirow{2}{*}{ Meristotheca papulosa } & MPA-1 & $\beta$-barrel & \multirow{2}{*}[8]{} \\
\hline & & & MPA-2 & $\beta$-barrel & \\
\hline & & \multirow{2}{*}{ Solieria filiformis } & SfL-1 & $\beta$-barrel & \multirow{2}{*}[15]{} \\
\hline & & & SfL-2 & $\beta$-barrel & \\
\hline
\end{tabular}


Table 1. Cont.

\begin{tabular}{|c|c|c|c|c|c|}
\hline Algae Phylum & Algae Family & Algae Species & Lectin & $\begin{array}{l}\text { Structural } \\
\text { Scaffold }\end{array}$ & Ref. \\
\hline \multirow{4}{*}{ Yellow- } & \multirow{4}{*}{ Legume-like } & Hydropuntia fisheri & HFA & $\beta$-sandwich & [Ac. GQ906709] \\
\hline & & Nannochloropsis gaditana & $\mathrm{NgL}$ & $\beta$-sandwich & [16] \\
\hline & & Porphyra umbilicalis & BU14 & $\beta$-sandwich & [Ac. OSX69288] \\
\hline & & Ostreococcus tauri & OtL & $\beta$-sandwich & [17] \\
\hline green algae & GNA-like & Boodlea coacta & BCA & $\beta$-prism II & [18] \\
\hline \multirow{3}{*}{ Green algae } & \multirow{2}{*}{ MFP2-like } & \multirow{2}{*}{ Bryopsis plumosa } & \multirow{2}{*}{ BPL-2 } & MFP2-like & \multirow{2}{*}{ [Ac. BAI43482] } \\
\hline & & & & scaffold? & \\
\hline & unknown & Halimeda renschii & HRL40-1/2 & $\beta$-prism I & [19] \\
\hline
\end{tabular}

\section{Structural Scaffolds of the Man-Specific Seaweed Lectins}

Mannose-specific lectins from seaweeds essentially belong to four distinct structural scaffolds corresponding to monomeric structures that occur as single carbohydrate-binding modules or subsequently arrange in homodimeric structures. In addition, complex proteins with different functions occurring in seaweeds contain a lectin domain corresponding to a carbohydrate-binding module (CBM) with man-specificity, e.g., the legume-lectin like domain in the BU14 protein of Porphyra umbilicalis [20].

\subsection{Griffithsin}

Griffithsin, the man-specific lectin from the red alga Griffithsia sp., was among the first man-specific lectins isolated and characterized from seaweeds [3]. The lectin consists of a single polypeptide chain of 122 amino acids which contains three putative N-glycosylation sites 46NLS, 72NIS and 105NGS. The X-ray crystal structures of griffithsin revealed a $\beta$-prism I organization similar to that found in artocarpin [21] and jacalin [22] from the Jackfruit Artocarpus integrifolia, banana lectin [23], and Heltuba from the Jerusalem artichoke Heliantus tuberosus [24] (Figure 1A-C). In fact, the lectin consists of a domain-swapped structure resulting from the symmetrical non covalent arrangement of two identical domains (Figure 2). Three carbohydrate-binding sites (CBS) disposed as a triangle at the edges of the $\beta$-prism domain, make the two domain-swapped griffithsin an hexavalent man-specific lectin.

\subsection{Oscillatoria Agardhii Agglutinin Homolog (OAAH) Family}

The largest phylum of Rhodophyta contains man-specific lectins which possess the Oscillatoria agardhii agglutinin homolog (OAAH) scaffold [25]. The OAAH family comprises the ASL-1 and ASL-2 lectins from Agardhiella subulata [8], EDA-2 and ESA-2 from Eucheuma denticulatum [10], and E. serra [11,12], KAA-2 and KSA-2 from Kappaphycus alvarezeii and K. striatum [13,14], MEL from Meristiella echninocarpa [8], MPA-1 and MPA-2 from Meristotheca papulosa [8], and SfL-1 and SfL-2 .from Solieria filiformis [13]. The so-called OAAH scaffold consists of a single polypeptide chain formed by two repeats of five $\beta$-strands, organized in a compact 10-stranded $\beta$-barrel structure. Two $\beta$-barrels associate perpendicularly to build up the complete molecule (Figure $1 \mathrm{C}, \mathrm{D}$ ). This structural scaffold was first identified in the cyanobacterial Oscillatoria agardhii lectin (PDB code 3OBL) [26,27], and subsequently found in various red algae lectins. Three CBSs occurring at both ends of the OAAH scaffold make all these man-specific red algae lectins with two OAAH scaffolds, tetravalent lectins. 

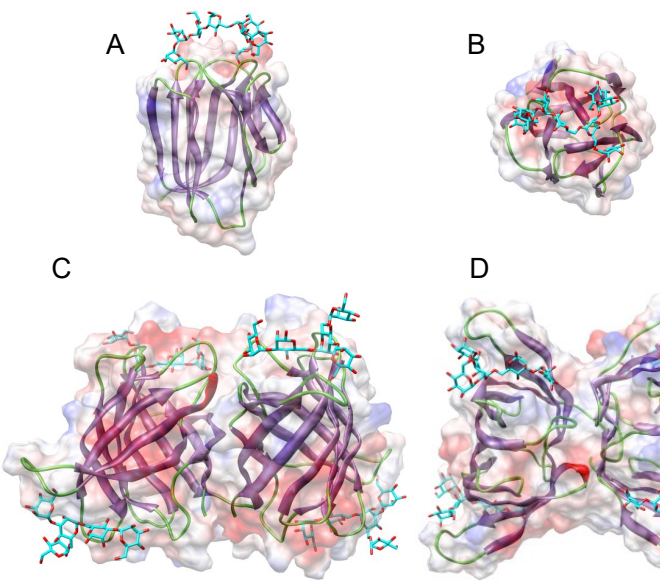

D
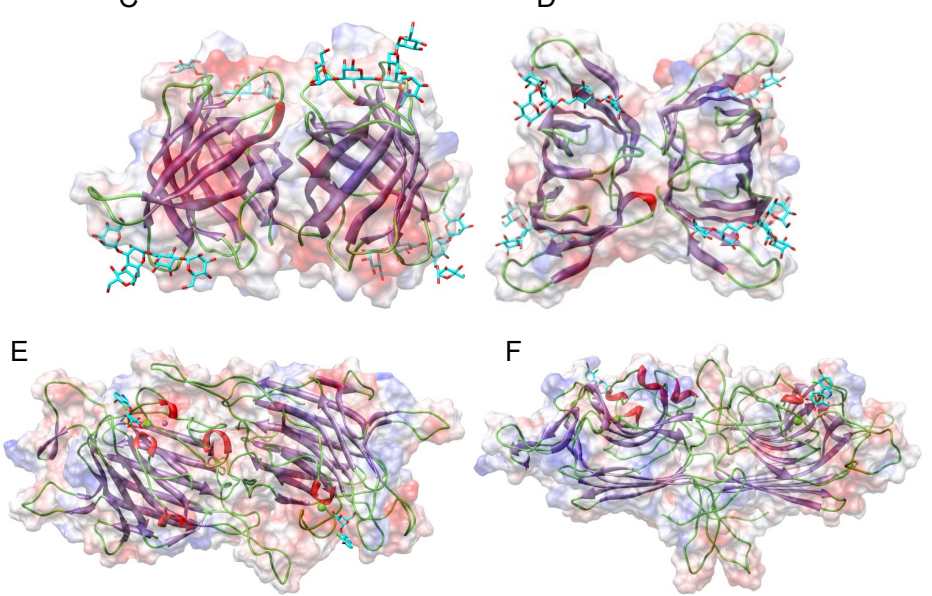

Figure 1. Structural diversity of the mannose-binding seaweed lectins. (A,B). Lateral (A) and front (B) views of the ribbon diagram of griffithsin monomer (protein data bank (PDB) code 1LL2) in complex with a pentamannoside (colored cyan), showing the $\beta$-prism-I organization of strands of $\beta$-sheet. Surface electrostatic potential (electronegatively and electropositively charged surfaces colored in red and blue, respectively; neutral surfaces colored grey) is shown in transparency. (C,D). Lateral (C) and front (D) views of the ribbon diagram of the modelled Agardhiella subulata lectin ASL-1, in complex with a pentamannoside (colored cyan), showing the $\beta$-barrel organization of strands of $\beta$-sheet. Surface electrostatic potential is shown in transparency. (E,F). Lateral (E) and front (F) views of the ribbon diagram of the modelled lectin from Ostreococcus tauri OtL, in complex with a dimannoside (colored cyan), showing the $\beta$-sandwich organization of strands of $\beta$-sheet. Surface electrostatic potential is shown in transparency. ASL-1 and OtL lectins were modelled with YASARA, and rendered with Chimera.

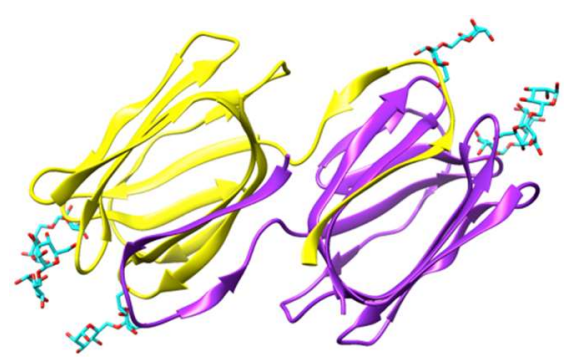

Figure 2. Ribbon diagram showing the domain-swapped structure of griffithsin, organized in two symmetrical domains colored purple and yellow, respectively (PDB code $2 \mathrm{HYQ}$ ), in complex with six $\alpha$ 1,6-mannobiose ligands (colored cyan). In each domain, the carbohydrate-binding sites (CBS) are located at the top of the $\beta$-prism structure. Molecular cartoon drawn with Chimera.

\subsection{Legume Lectin-Like Family}

The $\beta$-sandwich jelly roll scaffold found in legume lectins (Fabaceae), also occurs in various man-specific lectins from different algae species including the green alga Ostreococcus tauri OtL [17], the brown alga Hydropuntia fisheri HfL, the yellow brown alga Nannochloropsis gaditana NgL [16], and the red alga Porphyra umbilicalis which possesses a BU14 protein containing a typical legume-lectin domain [20] (Table 1). The O. tauri lectin consists of a homodimer resulting from the non-covalent association of two identical protomers. Each protomer consists of a single polypeptide chain organized 
in two antiparallel $\beta$-sheets of six and seven strands, respectively, to form a $\beta$-sandwich structure (Figure 1E,F). This three-dimensional organization is reminiscent of the homodimeric lectin from Lathyrus nissolia [28] and L. sphaericus [29] in the viciae tribe of Fabaceae. Red algae lectins differ from other homodimeric two-chain lectins of the Viciae tribe, e.g., pea lectin (Pisum sativum agglutinin PsA) [30], lentil lectin (Lens culinaris agglutinin LcA) [31], yellow vetch lectin (Lathyrus ochrus lectin Lol) [32] (Figure 1B), and the faba bean lectin (Vicia faba agglutinin VfA or favin) [33], which contain protomers cleaved into a light $(\alpha)$ and a heavy $(\beta)$ chain. However, like other viciae lectins, they possess two identical mannose-binding sites. They also differ from the single-chain legume lectins, which result from the non-covalent association of four protomers to give homotetrameric mannose-binding lectins occurring in the tribes Baphieae (Bowringia mildbraedii agglutinin BMA) [34], Dalbergieae (Centrolobium tomentosum lectin CTL [35], Pterocarpus angolensis lectin PAL [36]), Diocleae (Con A [37], Cymbosema roseum CRL [38], Dioclea grandiflora lectin Con GF [39], and other Dioclea sp. lectins), which exhibit four mannose-binding sites. Other man-specific lectins like HfL from Hydropuntia fisheri, NgL from Nannochloropsis gaditana and the legume-lectin domain of the BU14 protein from Porphyra umbilicalis, more closely resemble the $\beta$-sandwich monomeric structure found in the canine ViP36 lectin (PDB code 2DUR) [40] and the rat p58/ERGIC-53 lectin (PDB code 1GV9) [41], which are similarly built up from two $\beta$-sheets of six and seven strands of antiparallel $\beta$-sheet associated in a $\beta$-sandwich structure (Figure 3). In all of these lectins with a jelly roll scaffold, a single CBS occurs at the confluence of the $\beta$-sheets, at the top of the $\beta$-sandwich structure. Moreover, in all of these legume-related lectins, some of the amino acid residues forming the CBS also serve to coordinate $\mathrm{Ca}^{2+}$ cation in close proximity, contributing to the conformational stability to the CBS.

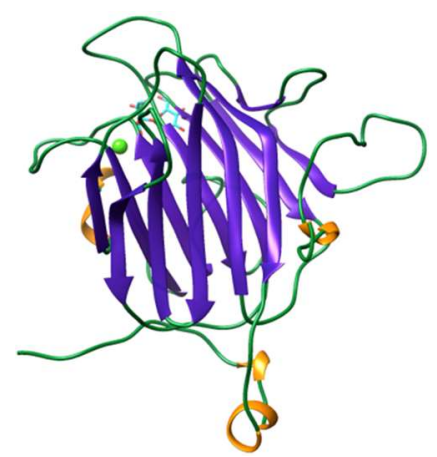

(A)

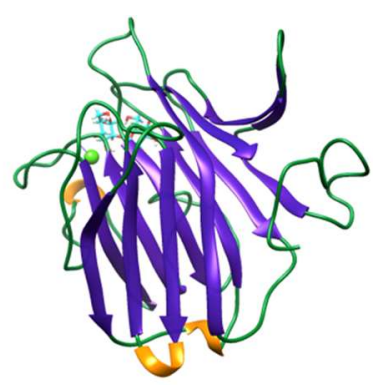

(B)

Figure 3. Stereo view showing the conservation of the $\beta$-sandwich core between VIP36 protein (PDB code 2DUR) used as a template (A), to model the legume-like lectin HFA from Hydropuntia fisheri (B) in complex with a dimannoside (colored cyan), using YASARA. The $\mathrm{Ca}^{2+}$ ion is colored yellow green. The amino acid sequences of proteins share $27.5 \%$ identity and $72.5 \%$ similarity, and a RMSD between 176 pruned atom pairs and across all 209 atom pairs were $0.908 \AA$ and $2.576 \AA$, respectively, using the Needleman-Wursch alignment algorithm and the BLOSUM 62 homology matrix. Molecular cartoon drawn with Chimera.

\subsection{GNA-Like Family}

The $\beta$-prism-II scaffold, also known as monocot-lectin or GNA-like scaffold, consists of three bundles of four $\beta$-strands arranged into a flattened $\beta$-prism structure around a central pseudoaxis. A carbohydrate-binding site occurs in a groove located at the center of the bundle of $\beta$-strands forming each $\beta$-sheet. The man-specific lectin BCA from the brown alga Boodlea coacta, [18], exhibits a similar scaffold (Figure 4), and docking experiments performed in silico suggest that both CBSs of BCA are fully active and readily accommodate a mannose residue (see Section 4.4). 


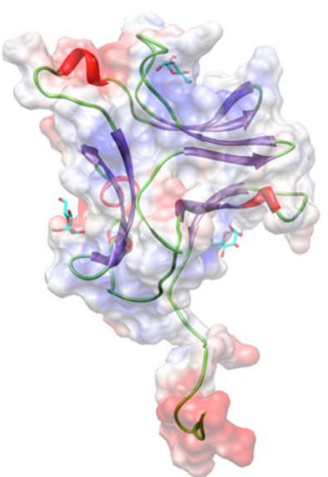

(A)

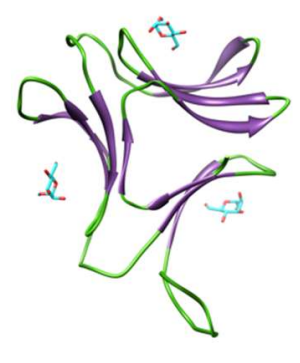

(B)

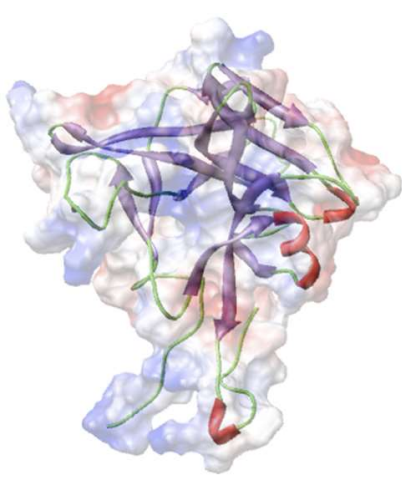

(C)

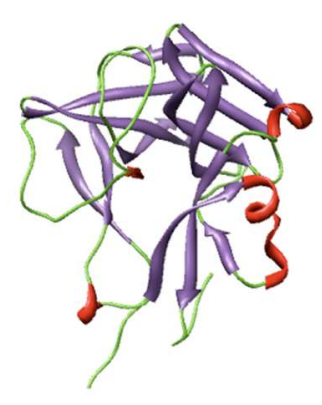

(D)

Figure 4. (A,B) Ribbon diagram of the three-dimensional model built up for the Boodlea coacta lectin BCA (A), compared to GNA (PDB code 2MSA) (B) used as a template for homology modelling (15\% identity and 51\% similarity, RMSD between 46 atom pairs: 0.457$)$. Surface electrostatic potential (electronegatively and electropositively charged surfaces colored in red and blue, respectively; neutral surfaces colored grey) of BCA are indicated and mannose residues anchored to the CBSs of the lectin are colored cyan. (C,D) Ribbon diagram of the modelled BPL-2 lectin from Bryopsis plumosa (C), compared to MFP2 (PDB code 2BJR) (D) used as a template for homology modelling (19.5\% identity and $48 \%$ similarity, RMSD between 82 atom pairs: $0.698 \AA$ ). Surface electrostatic potential (electronegatively and electropositively charged surfaces colored in red and blue, respectively; neutral surfaces colored grey) of BCA are indicated. Molecular cartoon drawn with Chimera.

\subsection{MFP2-Like Family}

The lectin BPL-2 from the green-yellow alga Bryopsis plumosa, has been characterized as a man-specific lectin structurally-related to MFP2, a protein involved in the nematod sperm cell mobility [42]. The lectin consists of three $\beta$-harpins which adopt a triangular disposition to form a sort of $\beta$-trefoil structure (Figure 4). In silico docking experiments performed with mannose, suggest the occurrence of a single active CBS in the BPL-2 lectin (see Section 4.5).

Other man-specific lectins have been isolated and characterized from other alga species, e.g., HLR40-1 and HLR40-2 from the green alga Halimeda renschii [16], and EPL-1 and EPL-2 from the green alga Enteromorpha (Ulva) prolifera [43], but none of them resembles the already known seaweed lectin families and thus, no information is yet available on their three-dimensional structures.

Lectins with carbohydrate-binding specificities similar to griffithsin, have been isolated and characterized from bacteria, e.g., cyanovirin-N (CV-N) from the cyanobacterium Nostoc ellipsosporum [44], and fungi, e.g., actinohivin (AH) from the Actinomycete Longispora albida [45], which both displayed anti-HIV activity [46]. The cyanovirin-N lectin domain consists of a $\beta$-barrel (PDB code 2EZM) [47], whereas the actinovirin lectin domain exhibits a $\beta$-trefoil architecture (PDB code 3A07) [48]. The accommodation of high-mannose glycans by both lectins, closely resembles that found in griffithsin and other man-specific seaweed lectins, with a prominent role for the oligosaccharide-binding pocket in the CBSs [49,50], (Figure 5). 


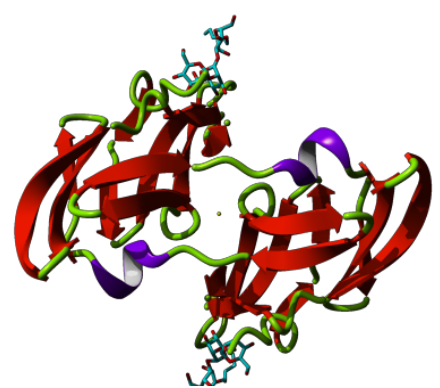

(A)

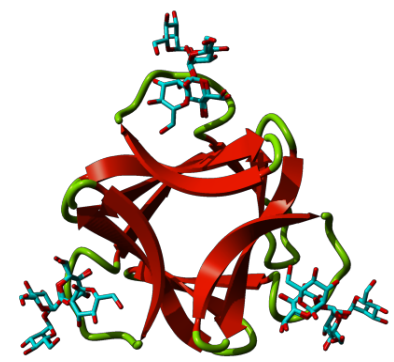

(B)

Figure 5. (A) Ribbon diagram of the domain-swapped cyanovirin- $N$ dimer, in complex with a trimannoside oligosaccharide (cyan colored sticks) at the CBS located at the top of the $\beta$-barrel structures (PDB code 3GXY). (B) Front view of the ribbon diagram of actinohivin complexed to a tetramannoside oligosaccharide (cyan colored sticks) at the CBS located at the edges of the $\beta$-trefoil structure (PDB code 4P6A). Molecular cartoon drawn withYASARA.

\section{Mannose-Binding Specificities of Mannose-Binding Seaweed Lectins}

Extensive X-ray crystallographic studies of different lectins complexed to simple and complex carbohydrates revealed the occurrence of two types of closely interlinked carbohydrate-binding specificities at the CBS of plant, algal and fungal lectins [7]:

- A monosaccharide-binding specificity, allowing the lectins to specifically recognize a simple sugar, e.g., mannose, and its derivatives, e.g., $\alpha$-methylmannoside. This monosaccharide recognition corresponds to the "broad sugar-binding specificity" that allows lectins to accommodate simple sugars in a monosaccharide-binding pocket located within the CBS.

- An oligosaccharide-binding specificity, allowing the lectins to simultaneously accommodate several sugar units of a complex $N$-glycan, e.g., high-mannose glycans, also known as the "fine sugar-binding specificity" of the lectins. This oligosaccharide recognition involves the whole surface of the CBS, including the monosaccharide-binding pocket, which also participates in the binding of the complex glycans.

\subsection{Griffithsin}

The binding of simple sugars (Man, Glc, GlcNAc), dimannoside ( $\alpha$ 1,6-mannobiose, maltose) and complex tri-branched high-mannose glycan (Man9GlcNAc2) to griffithsin, has been investigated by X-ray crystallography at atomic resolution (Table 2).

Table 2. PDB codes of lectins from seaweeds, complexed to mannose, glucose, $N$-acetyl-glucosamine, maltose and high-mannose glycans.

\begin{tabular}{lllc}
\hline Algae Species & Lectin & \multicolumn{1}{c}{ PDB Code (Complexed Sugar) } & Ref. \\
\hline & & 2GUC, 2GUD (Man) & {$[51]$} \\
& 2NUO (Glc) & {$[52]$} \\
Griffithsia sp. & griffithsin & 2GUE (GlcNAc), 2NU5 (GlcNAc) & {$[51,52]$} \\
& & 2HYQ $(\alpha 1,6$-mannobiose), 2HYR (maltose) & {$[53]$} \\
& & 3LL2 (9ManGlcNAc2) & {$[54]$} \\
\hline
\end{tabular}

A network of seven hydrogen bonds between O3, O4, O5 and O6 of mannose and Ser27, Tyr28, Asp30 and Gly44 of CBS I, Asp67, Tyr68, Asp70 and Gly90 of CBS II, Asp109, Tyr110 and Asp112 of CBSIII, accommodates the simple sugar in the monosaccharide-binding pocket of the three CBSs located at the top of the griffithsin domain (Figure 6A). Aromatic Tyr28, Tyr68 and Tyr110 residues also participate in stacking interactions with the pyranose ring of the mannose residues, that reinforces the binding of mannose to the CBS. The occurrence of Asp residues in the monosaccharide-binding 
pocket communicates a strong electronegative character to the griffithsin CBSs (Figure 6B). A very similar binding scheme has been observed in the griffithsin monomer complexed to glucose (PDB code 2NUO) [52], and GlcNAc (PDB codes 2GUE and 2NU5) [51,52].

A

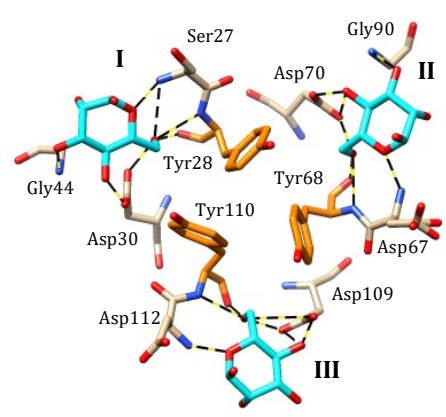

C

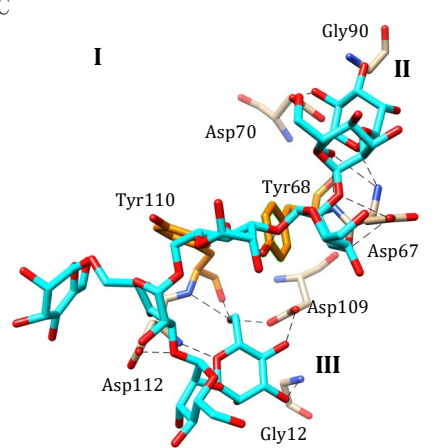

B

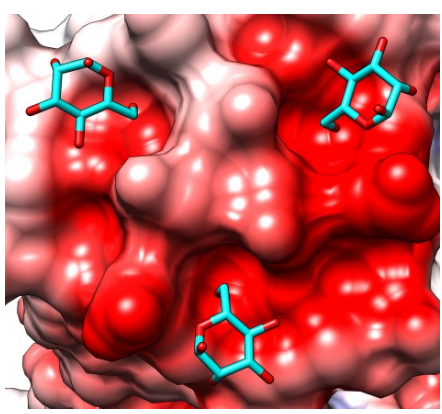

D

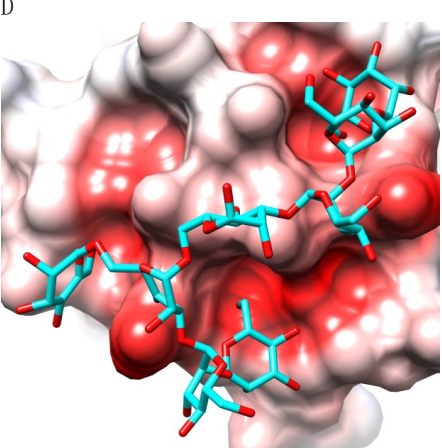

Figure 6. Accommodation of mannose $(\mathbf{A}, \mathbf{B})$ and high-mannose type glycan $(\mathbf{C}, \mathbf{D})$ at the carbohydrate-binding sites of griffithsin (PDB codes 2GUD and 3LL2, respectively). (A) Network of hydrogen-bonds (dashed black lines) anchoring mannose to the three CBSs I, II and III, located at the top of monomer A in the dimeric structure of griffithsin (PDB code 2GUD). Stacking interactions occur between tyrosine residues Tyr28 (site I), Tyr68 (site II) and Tyr110 (site III) and the pyranose ring of mannose ligands. Water-mediated H-bonds that participate in the binding of mannose to the CBSs are not represented. (B) Coulombic charges (electronegative, electropositive and neutral regions are colored red, blue and white, respectively) at the molecular surface of griffithsin, showing the strong electronegative (acidic) character of the CBDs. (C) Network of hydrogen-bonds (dashed black lines) anchoring a high-mannose type glycan to the CBDs of griffthsin (PDB code 3LL2). Note that CBD I does not participate in the binding of the glycan. Stacking interactions occur between tyrosine residues Tyr68 (site II) and Tyr110 (site III) and the pyranose ring of the high-mannose glycan. Water-mediated $\mathrm{H}$-bonds that participate in the binding of high-mannose glycan to the CBDs and the surrounding regions, are not represented. (D) Coulombic charges (electronegative, electropositive and neutral regions are colored red, blue and white, respectively) at the molecular surface of griffithsin, showing how the high-mannose glycan chain is accommodated by the strong electronegative (acidic) CBDs and the surrounding regions. Note that the acidic pocket corresponding to CBS I does not participate in the binding of the glycan.

The binding of disaccharides, $\alpha 1,6$-mannobiose (PDB code 2HYQ) and maltose (PDB code 2HYR) to the griffithsin CBS [53], reveals a very similar binding scheme with a single sugar unit anchored to the monosaccharide-binding pocket via a similar network of hydrogen bonds and stacking interactions with Tyr residues (result not shown). No interaction occurs between the second sugar unit of the disaccharide and the CBS.

The accommodation of more complex sugars by griffithsin, e.g., a tri-antennary high-mannose glycan chain Man9GlcNAc2 (PDB code 3LL2) [54], reveals a multisite interaction between the glycan and CBS II and CBS III of the lectin, the first CBS I remaining vacant and not involved in the interaction 
with the sugar units of the complex glycan (Figure 6C,D). Only two mannose units located at both ends of the complex high-mannose glycan chain, readily interact with the monosaccharide-binding pocket of CBS II and CBS III via a network of hydrogen bonds and stacking interactions involving the same amino acid residues insuring the anchorage of simple sugars to the CBSs. No contact occurs between other sugar units of the complex glycan and the griffithsin domain (Figure 1A). This multisite binding scheme readily differs from that observed in other plant, algal and fungal lectins, which establish hydrogen bonds and stacking interaction with several sugar units to properly accommodate complex glycans at their extended oligosaccharide-binding site. In this respect, griffithsin uses a similar binding scheme to accommodate both simple sugars, dimannosides and complex high-mannose glycans, which only involves the monosaccharide-binding pockets located at the top of both domains. Finally, the ability to mediate multisite and multivalent interactions with simple sugars accounts for the high affinity and activity of griffithsin toward high-mannose glycans and thus explains the potential anti-viral and anti-cancer activities of the lectin.

\subsection{OAAH Lectins}

Docking of a two-branched pentamannosyl glycan to the CBS of the modelled EDA-2, the OAAH lectin from the red alga Eucheuma denticulatum, reveals an oligosaccharide-binding scheme very similar to those found in plant lectins, especially in legume lectins, involving an extended area around the monosaccharide-binding pocket. A mannose unit anchors to the monosaccharide-binding pocket while other mannose units interact with amino acid residues located in the vicinity of the pocket via a network of hydrogen bonds and a stacking interaction with the aromatic Trp10 residue (Figure 7A). Like in other lectins, the monosaccharide-binding pocket exhibits a strong electronegative (acidic) character (Figure 7B). Docking experiments performed with other modelled OAAH lectins, e.g., the Solieria filiformis SfL-1 and SfL-2 lectins, revealed a very similar oligosaccharide-binding scheme at the extended CBS of the lectins.

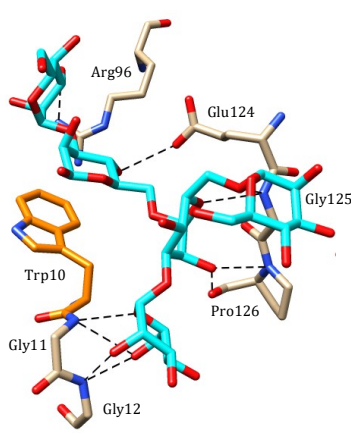

(A)

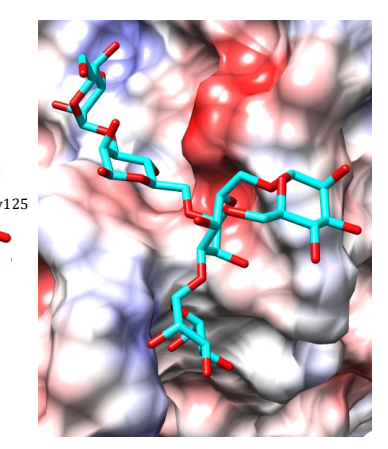

(B)

Figure 7. Accommodation of a pentamannosyl glycan (A,B) at the carbohydrate-binding site of EDA-2, the Eucheuma denticulata lectin (modelled and docked, using the PDB code 3OBL as a template). (A) Network of hydrogen-bonds (dashed black lines) anchoring the pentamannosyl glycan to the CBS. Stacking interactions occur between tryptophan residue Trp10 and a pyranose ring of the ligand. Water-mediated H-bonds that participate in the binding of pentamannosyl glycan to the CBS are not represented. (B) Coulombic charges (electronegative, electropositive and neutral regions are colored red, blue and white, respectively) at the molecular surface of EDA-2, showing the electropositively (blue) and electronegatively (red) charged regions in contact with the pyranose rings of the ligand.

\subsection{Legume Lectin-Like Seaweed Lectins}

The accommodation of $\alpha 1,6$-mannobioside to the CBS of the Hydropuntia (Gracilaria) fisheri man-specific lectin (HFA), obeys the oligosaccharide-binding scheme found in legume lectins like Con A and Con A-like lectins [2]. Both mannose units of the disaccharide bind to amino acids located in and close to the monosaccharide-binding site via a network of hydrogen bonds. Additional stacking 
interactions occurring between the pyranose ring of the mannose units and two aromatic Phe112 and Phe114 residues, complete the interaction of the dimannoside with the CBS (Figure 8A).

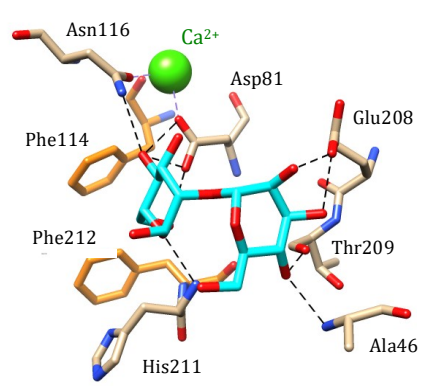

(A)

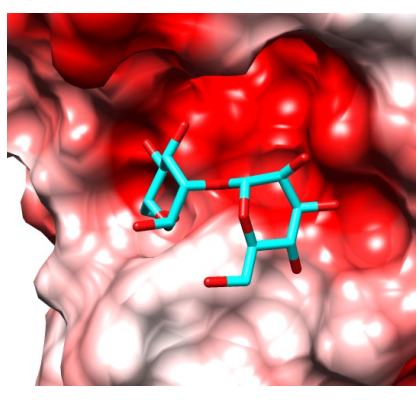

(B)

Figure 8. Accommodation of a dimannoside $(\mathbf{A}, \mathbf{B})$ at the carbohydrate-binding site of HFA, the Hydropuntia fisheri lectin (modelled and docked, using the PDB code 2DUR as a template). (A) Network of hydrogen-bonds (dashed black lines) anchoring the dimannoside to the CBS. Stacking interactions occur between phenylalanine residue Phe114 and Phe212, and a pyranose ring of the ligand. (B) Coulombic charges (electronegative, electropositive and neutral regions are colored red, blue and white, respectively) at the molecular surface of HFA, showing the electronegatively (red) charged of the carbohydrate-binding cavity that harbors the sugar.

Like in other man-specific lectins, the monosaccharide-binding pocket displays a pronounced electronegative (acidic) character (Figure 8B). In addition, like in legume lectins, some of the amino acid residues involved in the H-bond network, e.g., Asp81 and Asn116, also serve as ligands for a $\mathrm{Ca}^{2+}$ cation, that reinforces the stability of the CBS and contributes to improve the affinity of the legume lectin-like HFA for mannose and high-mannose glycans.

\subsection{GNA-Like Seaweed Lectins}

The GNA-like seaweed lectin BCA from the brown alga Boodlea coacta accommodates mannose at the CBS II via a network of hydrogen bonds linking the O2, $\mathrm{O} 3$ and $\mathrm{O} 4$ of mannose to residues Gln66, Asp68 and Glu70 forming the monosaccharide-binding pocket of the lectin (Figure 9A). An additional stacking between the pyranose ring of mannose and the aromatic Trp72 residue, complete the interaction. This monosaccharide-binding scheme which also occurs at BBS I and GBS III, strikingly resembles those occurring in the lectins from the monocot mannose-binding or GNA-like lectin family [3]. Calculation of the surface electrostatic potential of BCA indicates a pronounced electronegative (acidic) character of the surface area around the CBSs (Figure 9B), and suggests the capacity for BCA to also accommodate oligomannosidic glycans. In fact, investigations on the oligomannoside-specificity of BCA using a centrifugal ultrafiltration-HPLC technique, have shown that BCA only recognizes high-mannose glycan chains displaying $\alpha 1$,2-linked mannose at the non-reducing terminus [18], which can explain the higher affinity of BCA for $\alpha 1$,2-mannose clusters comprising three terminal $\alpha 1$,2-linked mannose units (Figure 10).

The exclusive specificity for the clusters of terminal $\alpha 1,2$-linked mannose units groups BCA apart from other man-specific seaweed lectins

\subsection{MFP2B-Like Seaweed Lectins}

Docking of mannose to the CBS of the modelled BPL-2, the Bryopsis plumosa lectin, suggests a monosaccharide-binding scheme very similar to those observed in other man-specific seaweed lectins (Figure 11A). A network of hydrogen bonds between $\mathrm{O} 1, \mathrm{O} 2, \mathrm{O} 3, \mathrm{O} 4$ and $\mathrm{O} 6$ of mannose and amino acids Lys123, Asp125, Ser154, Asp163 and Val164 forming a monosaccharide-binding pocket, allows the accommodation of the sugar to the CBS of the lectin. An additional stacking interaction occurs 
between the pyranose ring of mannose and Phe165. The surface around the monosacchaide-binding pocket exhibits an electronegative (acidic) character (Figure 11B).

Finally, the accommodation of high-mannose glycan chains by the man-specific seaweed lectins consists of a complex interaction process in which the monosaccharide-binding pocket plays a prominent role. Similarly, the mannose-binding pocket of the closely-related bacterial lectin cyanovirin-N [49] and fungal lectin actinohivin [50], plays a key role in the accommodation of high-mannose glycans (see Figure 5).

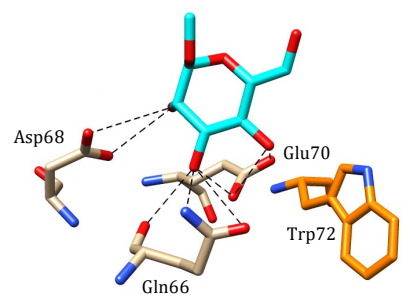

(A)

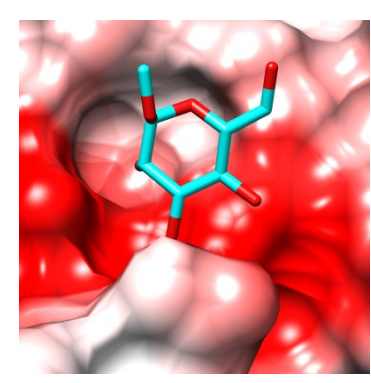

(B)

Figure 9. Accommodation of mannose $(\mathbf{A}, \mathbf{B})$ at the carbohydrate-binding site II of BCA, the Boodlea coacta lectin (modelled and docked, using the PDB code 1MSA as a template). (A) Network of hydrogen-bonds (dashed black lines) anchoring mannose to the CBS. A stacking interaction occurs between tryptophane residue Trp72 and the pyranose ring of the ligand. (B) Coulombic charges (electronegative, electropositive and neutral regions are colored red, blue and white, respectively) at the molecular surface of BCA, showing the electronegatively (red) charged character of the carbohydrate-binding cavity that harbors the sugar.

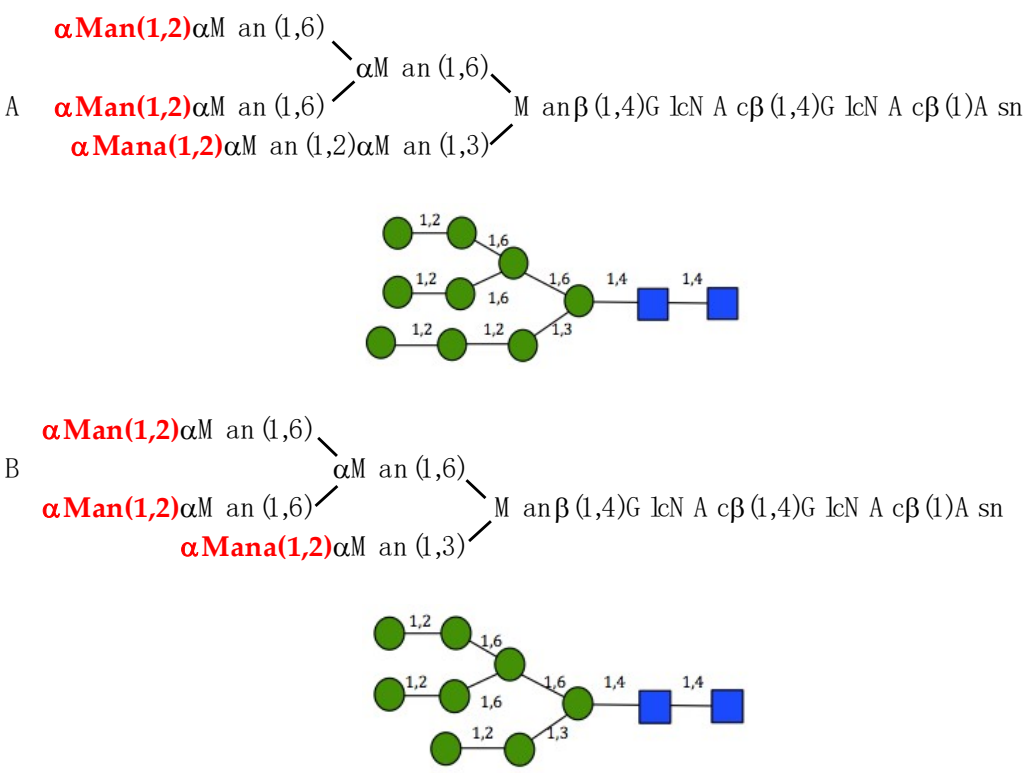

Figure 10. (A,B) High-mannose glycan chains displaying the higher affinity for BCA. The clusters of terminal $\alpha 1,2$-linked mannose units are shown in red bold letters in both oligosaccharidic structures. Symbols for man $(O)$ and GlcNAc $(\square)$ were used to draw the molecular cartoons of high-mannose glycan chains. 


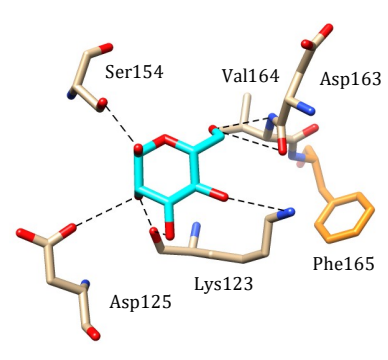

(A)

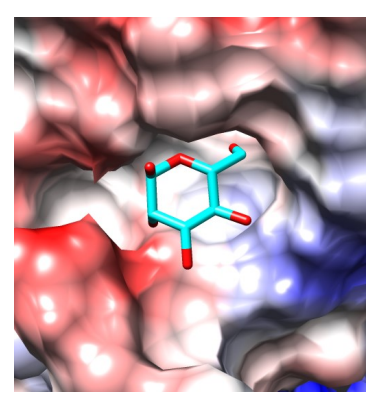

(B)

Figure 11. Accommodation of mannose (A,B) at the carbohydrate-binding site of BPL-2, the Bryopsis plumosa lectin (modelled and docked, using the PDB code 2BJR as a template). (A) Network of hydrogen-bonds (dashed black lines) anchoring mannose to the CBS. A stacking interaction occurs between phenylalanine residue Phe165 and the pyranose ring of the ligand. (B) Coulombic charges (electronegative, electropositive and neutral regions are colored red, blue and white, respectively) at the molecular surface of BPL-2, showing the electronegatively (red) charged character around the carbohydrate-binding cavity that harbors the sugar.

\section{Phylogenetic Relationships between Mannose-Binding Seaweed Lectins and Higher Plants}

The structural resemblance between man-specific lectins from seaweeds and higher plants, raises questions related to the phylogenetic relationships between these man-specific lectins. Compared to the corresponding lectin domains occurring in higher plants, seaweed lectins display amino acid sequences with some degree of conservation, e.g., the comparison between griffithsin and the $\beta$-prism I domain found in jacalin-related lectins from higher plants (Figure 12).

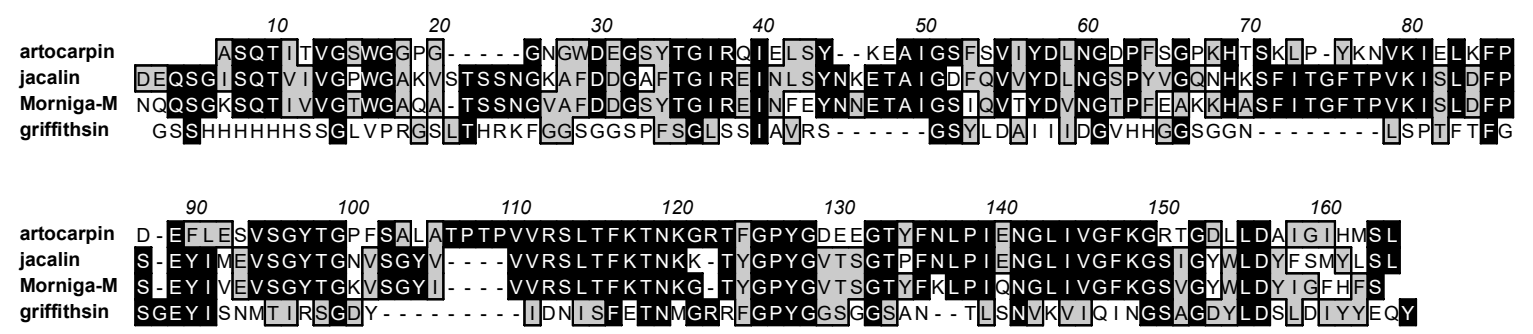

Figure 12. Multiple amino acid sequence alignment of griffithsin and jacalin-related lectins from higher plants (jacalin and artocarpin from Artocarpus integrifolia, frutalin from Artocarpus incisa, and Morniga-M from Morus nigra). Griffithsin shares 25\% identity and 70\% homology with jacalin-related lectins from higher plants. Sequence alignment was performed with CLUSTAL-X.

In fact, the jacalin-related $\beta$-prism I domain is widespread distributed in all of the living organisms either as an individual lectin, e.g., jacalin or griffithsin, or as a domain associated to other protein components of complex, multidomain proteins from bacteria, fungi and plants, displaying various metabolic functions [20]. In this respect, the man-specific lectins from red algae are more phylogenetically more closely-related to jacalin-related lectins from higher plants, compared to other jacalin-related lectins of fungal or bacterial origin, as shown in the phylogenetic tree built from the multiple amino acid sequence alignment of various jacalin-related lectins from plants, algae, fungi, bacteria and unicellular ciliates (Figure 13). This is not surprising since different genomes of Rhodophyta reveal some close phylogenetic relationships to Viridiplantae [55-58].

However, depending on the structural scaffold to which they belong, the degree of conservation of the man-specific seaweed lectin domains is extremely variable. Accordingly, the three tandemly arrayed $\beta$-prism II domains occurring in BCA, the brown alga Boodlea coacta lectin, share a weak degree of conservation compared to other $\beta$-prism II domains found in GNA and GNA-like lectins from higher 
plants, even though all of these lectin domains display a rather well conserved three-dimensional conformation, particularly of the core $\beta$-prism structure.

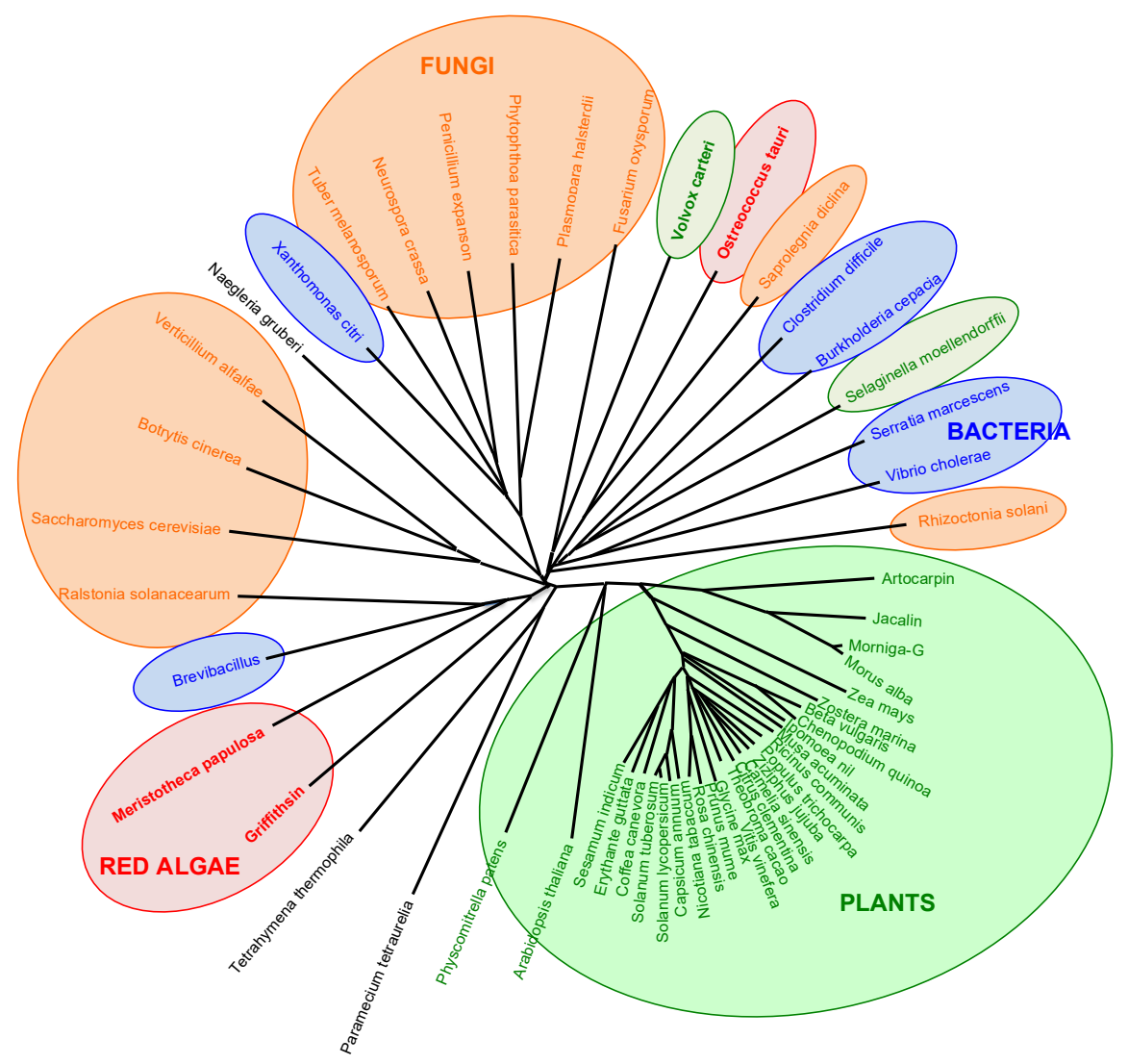

Figure 13. Phylogenetic tree built from the multiple amino acid sequence alignment of jacalin-related lectins from red algae (red boxes), plants (green box), fungi (orange boxes), and bacteria (blue boxes). Lectin of the green alga Volvox carteri is green boxed, and lectins from unicellular ciliates are not boxed.

\section{Biomedical Applications for the Man-Specific Seaweed Lectins}

Similar to man-specific lectins from higher plants, biomedical applications of man-specific seaweed lectins were especially applied in two directions, namely their virucidal properties against HIV and their anti-cancer properties.

\subsection{Mannose-Specific Seaweed Lectins as Virucidal Agents against HIV-I Infection}

Ever since the high-mannose moiety of $N$-glycans decorating the HIV-1 gp120 protein has been identified as a target recognized by the CD4+ T-lymphocytes in vitro, a step essential to later promote the virion infection of the host cells, man-specific lectins have been deeply investigated as possible agents able to mask the high-mannose target and thus prevent the HIV infection of the host cells by HIV. In fact, the tandem association of three gp120 molecules with three gp41 molecules forms the HIV-1-envelope spike, which consists of a transmembrane trimer of gp41 associated to an extracellular trimer of gp120 exhibiting the exposed high-mannose glycans necessary for the recognition process of HIV-1 by the CD4+ T-lymphocytes [59], (Figure 14). The tandem association of gp120 to gp41 results from the processing of the precursor gp160 by the host cell proteases.

The specific association of man-specific lectins to the high-mannose glycans of gp120 prevents the subsequent recognition of the HIV-1-envelope spikes by the coreceptors expressing cells, and thus acts as blocking agents for the entry of the HIV-1 virions into the host cells (Figure 15). Accordingly, the removal of two high-mannose $N$-glycans in gp120 resulted in an improved resistance of HIV-1 to griffithsin, the man-specific lectin from the red alga Griffithsia sp. [60]. In addition to griffithsin, 
grifonin-1 (GRFN-1), an 18-mer peptide derived from griffithsin, has also been investigated as a blocking agent against HIV-1 [61]. Moreover, other man-specific seaweed lectins were used as blocking agents for the infection in vitro of CD4+ T-lymphocytes by HIV-1 (Table 3).

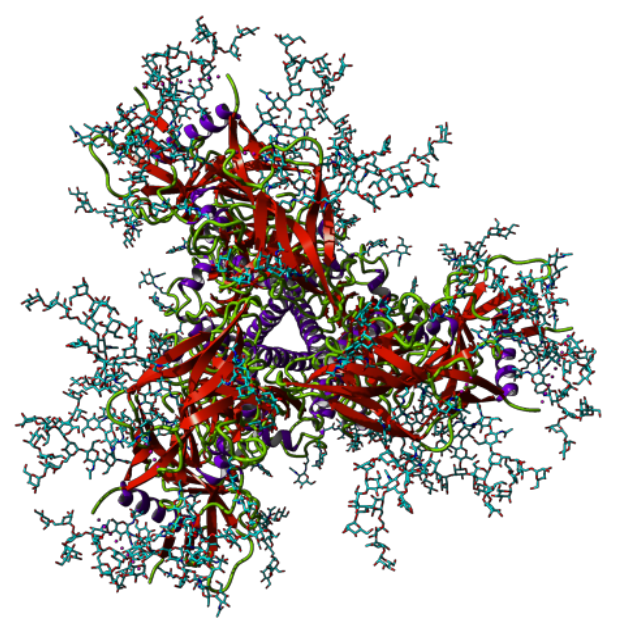

Figure 14. Ribbon diagram of the HIV-1-envelope spike built from the triangular association of three gp120 molecules (PDB code 5FYK). The gp41 molecules which are tandemly associated to the gp120 molecules, are not represented. The fully accessible high-mannose glycan chains that decorate the gp120 units are rendered as cyan colored sticks.

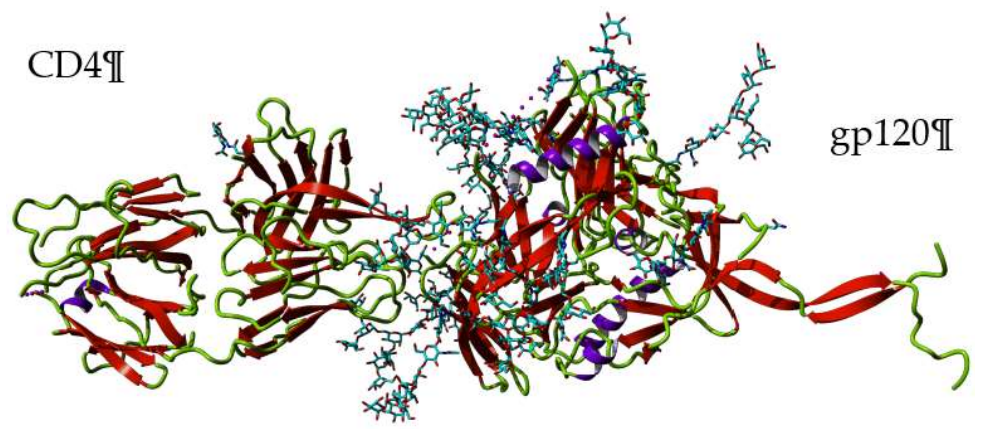

Figure 15. Three-dimensional structure of gp120 complexed to a CD4 molecule (PDB code 5FYK). The high-mannose $N$-glycan chain decorating gp120 are rendered as cyan colored sticks. Lectins which specifically bind to the high-mannose $N$-glycans exposed at the surface of gp120, interfere with the recognition of gp120 by the coreceptors of the CD4+ T lymphocytes.

Table 3. List of the man-specific seaweed lectins inhibiting HIV infection by binding to the viral gp120 envelope protein. $\mathrm{EC}_{50}$ is in the range between $0.1 \mathrm{nM}$ and $1.8 \mathrm{nM}$, depending on differences in methods used to quantify the anti-HIV activity of griffithsin in vitro. $\mathrm{IC}_{50}$ is usually less than $1.0 \mathrm{nM}$.

\begin{tabular}{cccc}
\hline Algae Phylum & Algae Family & Lectin & Ref. \\
\hline Red algae & Griffithsin & Griffithsin (Griffithsia sp.) & {$[4,54,61-79]$} \\
(Rhodophyta) & & GRFN-1 or Grifonin-1 (Griffithsia sp.) & {$[61]$} \\
& OAAH-like family & KAA-2 (Kappaphycus alvarezii) & {$[80]$} \\
Green algae & GNA-like family & BCA (Boodlea coacta) & {$[4,18]$} \\
(Chlorophyta) & Legume-like family & OtL (Ostreococcus tauri) & {$[17]$} \\
\hline
\end{tabular}

The-viral activity of griffithsin depends on its enhanced affinity for the high-mannose glycans decorating gp120 in the HIV-1-envelope spike, even at very low concentrations in the picomolar range. Interaction of griffithsin with gp120 does not prevent the recognition of gp120 by CD4 from the CD4+ T-lymphocytes, but prevents gp120 from interacting with its co-receptors, like e.g., DC-SIGN [64], that inhibits the DC-SIGN-mediated capture and transmission of HIV to CD4+ T-lymphocytes [70]. Due 
to the multivalent character of the griffithsin, which possesses three CBSs in each monomer of the dimeric structure, multiple interactions occurring between the lectin and the high-mannose glycans of gp120 favor the stability of the gp120-DC-SIGN complex and thus prevent the transmission of HIV to the CD4+ T-lymphocytes [54]. Even though griffithsin is considered an efficient and safe anti-viral agent $[63,68,76]$, the smaller 18-mer peptide derived from griffithsin, grifonin-1 (GRFN-1), should be an excellent substitute since it offers an equivalent anti-viral efficacy associated to a strongly reduced cytotoxicity [61].

The ability of griffithsin to interact in vitro with the exposed mannose residues of the $\mathrm{N}$-linked glycans from other envelope viruses, e.g., hepatitis $C$ virus [81,82], herpes virus [71,83], Ebola virus [73], coronavirus [84], and papilloma virus [83], make this carbohydrate-binding agent a potential broad-spectrum tool against various virus infection diseases. In this respect, KAA-2 from the red alga Kappaphycus alvarezii [13,80], and ESA-2 from thered alga Eucheuma serra [85], were shown to inhibit influenza virus infections by interfering with the virus envelope glycoprotein hemagglutinin.

Other Man-specific lectins of cyanobacterial origin were similarly identified as potent anti-HIV-1 proteins via their specific binding to the envelope gp120, as reported especially for actinohivin [48], cyanovirin-N [47], microvirin from Microcystis viridis [86], OAA from Oscillatoria agardhii [26], and scytovirin from Scytonema varium [66].

\subsection{Mannose-Specific Lectins as Cancer Biomarkers and Anti-Cancer Drugs}

The ability of man-specific plant lectins to discriminate between normal and diseased cancer cells, and specifically recognize the specific changes that have occurred in the high-mannose component covering tumor cells, also exists in man-specific seaweed lectins, allowing these proteins to be used as cytotoxic agents for various malignant cells [5,7]. Accordingly, several man-specific seaweed lectins have been investigated for their cytotoxic activity against various human and mouse cancer cell lines (Table 4).

Table 4. Cytotoxic effects of Man-specific lectins on cancer cells (reported during the last decade). Apopt.: apoptosis.

\begin{tabular}{cccccc}
\hline Phylum & Species & Lectin & Cancer cell & Apopt. & Ref. \\
\hline Red algae & $\begin{array}{c}\text { Agardhiella tenera } \\
\text { Bryoyhamnion seaforthii }\end{array}$ & ATA & BSL & mouse leukemia cell L5178Y & human colon carcinoma cells L5178Y \\
oligodendroglioma, ependymona, & [87] & {$[88]$} \\
& & & meningioma, medullo-blastoma & {$[89]$} \\
& Bryothamnion triquetrum & BTL & human colon carcinoma & + & {$[89]$} \\
& Eucheuma serra & ESA & Colo201, HeLa & + & {$[90]$} \\
& Solieria filiformis & SfL-1 & mouse Colon26 adenocarcinoma & + & {$[91]$} \\
& SfL-2 & Colo201 & + & {$[92]$} \\
& & human osteocarcinoma, murine & + & {$[93]$} \\
& & osteocarcinoma LM8 & MCF-7 & {$[15]$} \\
\hline
\end{tabular}

As reported for plant and fungal lectins [7], the recognition of the altered high-mannose glycans associated to the cancer cells by marine algal lectins, led to programmed cell death through the targeting of different apoptotic and autophagic pathways. At a concentration of $1.2 \mu \mathrm{g} \mathrm{mL} \mathrm{L}^{-1}$, ESA from Eucheuma serra provoked the apoptotic cell death of Colo201, HeLa and MCF-7 cells via the induction of the caspase-3-dependent pathway [90]. The expression of caspase-3 was similarly reported for mouse Colo26 and adenocarcinoma cells, treated in vitro and in vivo conditions by the E. serra lectin [91], and for Colo201 cells treated in vitro and in vivo conditions by Span 80 vesicles containing immobilized E. serra agglutinin [92]. The E. serra lectin ESA, also induced the apoptotic cell death of both murine and human osteosarcoma cells [93]. The cytotoxic effects of SfL from the red alga Solieria filiformis on MCF-7, also involve the induction of the apoptotic cell death with an over-expression of caspase-3, -8 and -9 [15]. 


\subsection{Other Biomedical Applications of Mannose-Specific Seaweed Lectins}

In addition to their anti-viral and anti-cancer properties, miscellaneous biomedical properties of the Man-specific seaweed lectins were investigated, including their anti-bacterial and anti-nociceptive properties, together with their pro-healing effects. An anti-depressant-like effect was also reported in mice for SFL, the man-specific lectin from the red alga Solieria filiformis, which likely depends on its interference with the dopaminergic system (Table 5).

Table 5. Other investigated biomedical properties of Man-specific seaweed lectins.

\begin{tabular}{ccccc}
\hline Alga Phylum & Alga Species & Lectin & Biomedical Property & Ref. \\
\hline Red algae & Eucheuma serra & ESA & Anti-bacterial & {$[94]$} \\
& Solieria filiformis & SfL & Anti-bacterial & {$[95]$} \\
& Solieria filiformis & SfL & Anti-nociceptive & {$[96]$} \\
& Solieria filiformis & SfL & Anti-depressant & {$[97]$} \\
& Bryothamnion seaforthii & BSL & Pro-healing & {$[98]$} \\
\hline
\end{tabular}

\section{Methods}

Pairwise and multiple amino acid sequence comparisons were performed with MacVector, using the CLUSTAL-X program [99]. Hydrophobic cluster analysis (HCA) [100], was performed on HCA plots generated at the RPBS web portal (http://www.mobyle.rpbs.univ-paris-diderot.fr), for the prediction of secondary features along the amino acid sequence of seaweed lectins. An unrooted phylogenetic tree was built up from the multiple alignment of jacalin-related lectins using the uncorrected neighbor joining method integrated in MacVector. No bootstrapping was performed. TreeView 1.6.6 [101], was used to draw the phylogenetic tree of jacalin-related lectins.

Homology modelling of seaweed lectins was performed with the YASARA Structure program [102], using various protein templates from the PDB, depending on the overall structural scaffold to which they belong (e.g., 3OBL of the cyanobacterium Oscillatoria agardhii for modelling the Agardhiella subulata lectin ASL-1, shown in Figure 1). PROCHECK [103], ANOLEA [104], and the calculated QMEAN scores $[105,106]$, were used to assess the geometric and thermodynamic qualities of the three-dimensional models.

For docking experiments, complex glycans were built using the GLYCAM web server [107], and SWEET II web server [108,109]. The autodockVINA module of YASARA Structure [110], was used to dock the carbohydrate ligand (treated as a flexible molecule) to the lectin model (treated as a rigid molecule). Docking experiments were performed at the SwissDock web server (http: //www.swissdock.ch) [111,112], as a control for our docking experiments.

Molecular cartoons were drawn with Chimera [113] and YASARA.

\section{Discussion}

Lectins represent a ubiquitous group of carbohydrate-binding proteins that have been identified in all living organisms [20]. Lectins with various carbohydrate-binding specificities, especially Gal/GalNAc-specific and man-specific lectins, have been characterized in all groups of algae, primarily in green algae or Chlorophyta, brown algae or Ochrophyta, and red algae or Rhodophyta [46]. Except for a few lectins built up from structural scaffolds with no apparent homology with those found in the different classes of plant lectins [114], many other seaweed lectins share structural scaffolds in common with higher plant lectins, e.g., the jacalin-related scaffold, the legume-lectin scaffold and the GNA-like scaffold, irrespective of their carbohydrate-binding specificity. Likely, these structural homologies reflect the phylogenetic relationships that have occurred between higher plants and seaweeds during evolution [20].

Mannose-specific seaweed lectins occur in different phyla of algae but red algae or Rhodophyta, are particularly rich in species containing man-specific lectins [115]. To date, much attention has been 
paid to red algae lectins because of their potential biomedical properties [5]. In this respect, griffithsin, a lectin with a strong affinity for high-mannose glycans, isolated from the red alga Griffithsia sp. [3], was extensively investigated due to its enhanced anti-viral properties against HIV-1 and other pathogenic enveloped viruses [5]. Compared to other bacterial and plant lectins used as HIV entry inhibitors, griffithsin was reported as an efficient drug, at extremely low concentrations in the picomolar range, and safer toward uninfected cells $[63,68,76]$. In addition, the smaller substitute, an 18-mer peptide derived from griffithsin, grifonin-1 (GRFN-1), offers an equivalent efficacy associated to an improved safety toward healthy cells [61].

Besides their anti-viral properties, man-specific seaweed lectins also display relevant cytotoxic properties against various cancer cells by virtue of their capacity to target specific changes that have occurred in the high-mannose glycans expressed at the cell surface of cancer cells [116-128].

In spite of their biomedical potentialities as anti-HIV and anti-cancer drugs, only very few biomedical applications have been initiated with Man-specific seaweed lectins, essentially because of the difficulties inherently associated to the large-scale production of natural products. Even though scalable manufacture has been proposed for griffithsin [63], and high yields of production were previously reported for the isolation of Euchema lectins [9], the large scale production of algal lectins still remains a difficult task associated with unprofitable industrial yields. Additionally, a few topical administrations of griffithsin in combination with Span 80 vesicles [92], and carrageenan [83,129], applications based on the use griffithsin to prevent different enveloped virus infections are rare. Similarly, the synergistic association of griffithsin to the tenofovir, maraviroc and enfuvirtide drugs [64], and other carbohydrate-binding agents (CBAs) like the monoclonal antibody $2 \mathrm{G} 12$ and microvirin (MVN) [130], have been proposed in topical microbicide applications. Previously, the Eucheuma serra lectin ESA, had been successfully immobilized on the surface of lipid vesicles and the resulting ESA-bearing lipid vesicles were shown to effectively bind to cancer cell lines Colo201 and HeLa [90]. Delivery of griffithsin from griffithsin-modified electrospun fibers was successfully tested as an efficient and safe delivery scaffold for preventing HIV infection [131]. Recently, the monoclonal antibody 2G12 was simultaneously produced in rice endosperm with griffithsin and cyanovirin-N and, unexpectedly, extracts of transgenic plants expressing both proteins were shown to display an enhanced in vitro binding to gp120 and synergistic HIV-1 neutralization [132].

Author Contributions: A.B., M.S. and H.B. provided the bibliographic information and analyses. P.R. provided the molecular cartoons and the docking pictures. E.J.M.V.D. and P.R. wrote the review.

Funding: This research received no external funding.

Conflicts of Interest: The authors declare no conflict of interest.

\section{Abbreviations}

$\begin{array}{ll}\text { CBA } & \text { Carbohydrate-binding agent } \\ \text { CBM } & \text { Carbohydrate-binding module } \\ \text { CBS } & \text { Carbohydrate-binding site } \\ \text { Con A } & \text { Concanavalin A } \\ \text { CVN } & \text { Cyanovirin N } \\ \text { GNA } & \text { Galanthus nivalis agglutinin } \\ \text { Heltuba } & \text { Helianthus tuberosus agglutinin } \\ \text { HIV } & \text { Human Immunodeficiency virus } \\ \text { LCA } & \text { Lens culinaris agglutinin } \\ \text { OAA } & \text { Oscillatoria agardhii agglutinin } \\ \text { PDB } & \text { Protein data bank } \\ \text { PsA } & \text { Pisum sativum agglutinin } \\ \text { VfA } & \text { Vicia faba agglutinin }\end{array}$




\section{References}

1. Wu, A.M.; Song, S.C.; Tsai, M.S.; Herp, A. A guide to the carbohydrate specificities of applied lectins-2. Adv. Exp. Med. Biol. 2001, 491, 551-585. [PubMed]

2. Van Damme, E.J.M.; Rougé, P.; Peumans, W.J. Plant lectins. In Carbohydrate-Protein Interactions: Plant Lectins; Kamerling, J.P., Boons, G.J., Lee, Y.C., Suzuki, A., Taniguchi, N., Voragen, A.G.I., Eds.; Elsevier: New York, NY, USA, 2007; pp. 564-599.

3. Mori, T.; O'Keefe, B.R.; Sowder, R.C., 2nd; Bringans, S.; Gardella, R.; Berg, S.; Cochran, P.; Turpin, J.A.; Buckheit, R.W., Jr.; McMahon, J.B.; et al. Isolation and characterization of griffithsin, a novel HIV-inactivating protein, from the red alga Griffithsia sp. J. Biol. Chem. 2005, 280, 9345-9353. [CrossRef] [PubMed]

4. Akkouh, O.; Ng, T.B.; Singh, S.S.; Yin, C.; Dan, X.; Chan, Y.S.; Pan, W.; Cheung, R.C.F. Lectins with anti-HIV activity: A review. Molecules 2015, 20, 648-668. [CrossRef] [PubMed]

5. Singh, R.S.; Walia, A.K. Lectins from red algae and their biomedical potential. J. Appl. Phycol. 2018, 30, 1833-1858. [CrossRef]

6. Van Damme, E.J.M.; Peumans, W.J.; Barre, A.; Rougé, P. Plant lectins: A composite of several distinct families of structurally and evolutionary related proteins with diverse biological roles. Crit. Rev. Plant Sci. 1998, 17, 575-692. [CrossRef]

7. Barre, A.; Bourne, Y.; Van Damme, E.J.M.; Rougé, P. Overview of the structure-function relationships of mannose-specific lectins from plants, algae and fungi. Int. J. Mol. Sci. 2019, 20, 254. [CrossRef] [PubMed]

8. Chaves, R.P.; da Silva, S.R.; da Silva, J.P.F.A.; Carneiro, R.F.; de Sousa, B.L.; Abreu, J.O.; de Carvalho, F.C.T.; Rocha, C.R.C.; Farias, W.R.L.; de Sousa, O.V.; et al. Meristiella echinocarpa lectin (MEL): A new member of the OAAH-lectin family. J. Appl. Phycol. 2018, 30, 2629-2638. [CrossRef]

9. Kawakubo, A.; Makino, H.; Ohnishi, J.; Hirohara, H.; Kanji, H. Occurrence of highly yielded lectins homologous within genus Eucheuma. J. Appl. Phycol. 1999, 11, 149-156. [CrossRef]

10. Hung, L.D.; Hirayama, M.; Ly, B.M.; Hori, K. Purification, primary structure, and biological activity of the high-mannose N-glycan-specific lectin from cultivated Eucheuma denticulatum. J. Appl. Phycol. 2015, 27, 1657-1669. [CrossRef]

11. Kawakubo, A.; Makino, H.; Ohnishi, J.; Hirohara, H.; Kanji, H. The marine alga Eucheuma serra J. Agardh, a high yielding source of two isolectins. J. Appl. Phycol. 1997, 9, 331-338. [CrossRef]

12. Hori, K.; Sato, Y.; Ito, K.; Fujiwara, Y.; Iwamoto, Y.; Makino, H.; Kawakubo, A. Strict specificity for high-mannose type N-glycans and primary structure of a red alga Eucheuma serra lectin. Glycobiology 2007, 17, 479-491. [CrossRef] [PubMed]

13. Sato, Y.; Morimoto, K.; Hirayama, M.; Hori, K. High mannose-specific lectin (KAA-2) from the red alga Kappaphycus alvarezii potently inhibits influenza virus infection in a strain-independent manner. Biochem. Biophys. Res. Commun. 2011, 405, 291-296. [CrossRef] [PubMed]

14. Hung le, D.; Sato, Y.; Hori, K. High-mannose N-glycan-specific lectin from the red alga Kappaphycus striatum (Carrageenophyte). Phytochemistry 2011, 72, 855-861. [CrossRef] [PubMed]

15. Chaves, R.P.; da Silva, S.R.; Nascimento Neto, L.G.; Carneiro, R.F.; Coelho da Silva, A.L.; Sampaio, A.H.; Lopes de Sousa, B.; Cabral, M.G.; Videira, P.A.; Teixeira, E.H.; et al. Structural characterization of two isolectins from the marine red alga Solieria filiformis (Kützing) P.W. Gabrielson and their anticancer effect on MCF-7 breast cancer cells. Int. J. Biol. Macromol. 2018, 107, 1320-1329. [CrossRef]

16. Corteggiani Carpinelli, E.; Telatin, A.; Vitulo, N.; Forcato, C.; D’Angelo, M.; Schiavon, R.; Vezzi, A.; Giacometti, G.M.; Morosinotto, T.; Valle, G. Chromosome scale genome assembly and transcriptome profiling of Nannochloropsis gaditana in nitrogen depletion. Mol. Plant. 2014, 7, 325-335. [CrossRef] [PubMed]

17. Derelle, E.; Ferraz, C.; Rombauts, S.; Rouze, P.; Worden, A.Z.; Robbens, S.; Partensky, F.; Degroeve, S.; Echeynie, S.; Cooke, R.; et al. Genome analysis of the smallest free-living eukaryote Ostreococcus tauri unveils many unique features. Proc. Natl. Acad. Sci. USA 2006, 103, 11647-11652. [CrossRef] [PubMed]

18. Sato, Y.; Hirayama, M.; Morimoto, K.; Yamamoto, N.; Okuyama, S.; Hori, K. High-mannose-binding lectin with preference for the cluster of $\alpha 1-2$-mannose from the green alga Boodlea coacta is a potent entry inhibitor of HIV-1 and influenza viruses. J. Biol. Chem. 2011, 286, 19446-19458. [CrossRef]

19. Mu, J.; Hirayama, M.; Sato, Y.; Morimoto, K.; Hori, K. A novel high-mannose specific lectin from the green alga Halimeda renschii exhibits a potent anti-influenza virus activity through high-affinity binding to the viral hemagglutinin. Mar. Drugs 2017, 15, 255. [CrossRef] 
20. Van Holle, S.; Van Damme, E.J.M. Messages from the past: New insights in plant lectin evolution. Front. Plant Sci. 2019, 10, 36. [CrossRef]

21. Pratap, J.V.; Jeyaprakash, A.A.; Rani, P.G.; Sekar, K.; Surolia, A.; Vijayan, M. Crystal structure of artocarpin, a Moraceae lectin with mannose specificity, and its complex with methyl- $\alpha$-D-mannose: Implications to the generation of carbohydrate specificity. J. Mol. Biol. 2002, 317, 237-247. [CrossRef]

22. Sankaranarayanan, R.; Sekar, K.; Banerjee, R.; Sharma, V.; Surolia, A.; Vijayan, M. A novel mode of carbohydrate recognition in jacalin, a Moraceae plant lectin with a $\beta$-prism fold. Nat. Struct. Biol. 1996, 3, 596-603. [CrossRef] [PubMed]

23. Singh, D.D.; Saikrishnan, K.; Kumar, P.; Surolia, A.; Sekar, K.; Vijayan, M. Unusual sugar specificity of banana lectin from Musa paradisiaca and its probable evolutionary origin. Crystallographic and modelling studies. Glycobiology 2005, 15, 1025-1032. [CrossRef] [PubMed]

24. Bourne, Y.; Zamboni, V.; Barre, A.; Peumans, W.J.; Van Damme, E.J.; Rougé, P. Helianthus tuberosus lectin reveals a widespread scaffold for mannose-binding lectins. Structure 1999, 7, 1473-1482. [CrossRef]

25. Sato, Y.; Okuyama, S.; Hori, K. Primary structure and carbohydrate binding specificity of a potent anti-HIV lectin isolated from the filamentous cyanobacterium Oscillatoria agardhii. J. Biol. Chem. 2007, 282, 11021-11029. [CrossRef] [PubMed]

26. Koharudin, L.M.; Gronenborn, A.M. Structural basis of the anti-HIV activity of the cyanobacterial Oscillatoria agardhii agglutinin. Structure 2011, 19, 1170-1181. [CrossRef] [PubMed]

27. Koharudin, L.M.I.; Furey, W.; Gronenborn, A.M. Novel fold and carbohydrate specificity of the potent anti-HIV cyanobacterial lectin from Oscillatoria agardhii. J. Biol. Chem. 2011, 286, 1588-1597. [CrossRef] [PubMed]

28. Yarwood, A.; Richardson, M.; Morphet, B.; Westby, M.; Père, D.; Rougé, P. The amino acid sequences of two atypical single-chain Vicieae isolectins from seeds of Lathyrus nissolia L. Phytochemistry 1988, 27, 1719-1721. [CrossRef]

29. Richardson, M.; Yarwood, A.; Rougé, P. The amino acid sequence of an atypical single-chain lectin from seeds of Lathyrus sphaericus (Retz.). FEBS Lett. 1987, 216, 145-150. [CrossRef]

30. Einspahr, H.; Pareks, E.H.; Suguna, K.; Subramanian, E.; Suddath, F.L. The crystal structure of pea lectin at 3.0-Å resolution. J. Biol. Chem. 1986, 261, 16518-16527.

31. Foriers, A.; Van Driessche, E.; De Neve, R.; Kanarek, L.; Strosberg, A.D. The subunit structure and N-terminal sequences of the $\alpha$-and $\beta$-subunits of the lentil lectin (Lens culinaris). FEBS Lett. 1977, 75, 237-240. [CrossRef]

32. Bourne, Y.; Abergel, C.; Cambillau, C.; Frey, M.; Rougé, P.; Fontecilla-Camps, J.C. X-ray crystal structure determination and refinement at $1.9 \AA$ A resolution of isolectin I from the seeds of Lathyrus ochrus. J. Mol. Biol. 1990, 214, 571-584. [CrossRef]

33. Reeke, G.N., Jr.; Becker, J.W. Three-dimensional structure of favin: Saccharide binding-cyclic permutation in leguminous lectins. Science 1986, 234, 1108-1111. [CrossRef] [PubMed]

34. Buts, L.; Garcia-Pino, A.; Wyns, L.; Loris, R. Structural basis of carbohydrate recognition by a Man $(\alpha 1-2)$ Manspecific lectin from Bowringia Milbraedii. Glycobiology 2006, 16, 635-640. [CrossRef] [PubMed]

35. Almeida, A.C.; Osterne, V.J.; Santiago, M.Q.; Pinto-Junior, V.R.; Silva-Filho, J.C.; Lossio, C.F.; Nascimento, F.L.; Almeida, R.P.; Teixeira, C.S.; Leal, R.B.; et al. Structural analysis of Centrolobium tomentosum seed lectin with inflammatory activity. Arch. Biochem. Biophys. 2016, 596, 73-83. [CrossRef] [PubMed]

36. Loris, R.; Imberty, A.; Beeckmans, S.; Van Driessche, E.; Read, J.S.; Bouckaert, J.; De Greve, H.; Buts, L.; Wyns, L. Crystal structure of Pterocarpus angolensis lectin in complex with glucose, sucrose, and turanose. J. Biol. Chem. 2003, 278, 16297-16303. [CrossRef] [PubMed]

37. Hardman, K.D.; Ainsworth, C.F. Structure of concanavalin A at 2.4- ̊ resolution. Biochemistry 1972, 11, 4910-4919. [CrossRef] [PubMed]

38. Rocha, B.A.; Delatorre, P.; Oliveira, T.M.; Benevides, R.G.; Pires, A.F.; Sousa, A.A.; Souza, L.A.; Assreuy, A.M.; Debray, H.; de Azevedo, W.F., Jr.; et al. Structural basis for both pro-and anti-inflammatory response induced by mannose-specific legume lectin from Cymbosema roseum. Biochimie 2011, 93, 806-816. [CrossRef] [PubMed]

39. Rozwarski, D.A.; Swami, B.M.; Brewer, C.F.; Sacchetini, J.C. Crystal structure of the lectin from Dioclea grandiflora complexed with core trimannoside of asparagine-linked carbohydrates. J. Biol. Chem. 1998, 273, 32818-32825. [CrossRef] 
40. Satoh, T.; Cowleson, N.P.; Hakamata, W.; Ideo, H.; Fukushima, K.; Kurihara, M.; Kato, R.; Yamashita, K.; Wakatsuki, S. Structural basis for recognition of high mannose type glycoproteins by mammalian transport lectin VIP36. J. Biol. Chem. 2007, 282, 28246-28255. [CrossRef]

41. Velloso, L.M.; Svensson, K.; Schneider, G.; Pettersson, R.F.; Lindqvist, Y. Crystal structure of the carbohydrate recognition domain of p58/ERGIC-53, a protein involved in glycoprotein export from the endoplasmic reticulum. J. Biol. Chem. 2002, 277, 15979-15984. [CrossRef]

42. Grant, R.P.; Buttery, S.M.; Ekman, G.C.; Roberts, T.M.; Stewart, M. Structure of MFP2 and its function in enhancing MSP polymerization in Ascaris sperm amoeboid motility. J. Mol. Biol. 2005, 347, 583-595. [CrossRef] [PubMed]

43. Ambrosio, A.L.; Sanz, L.; Sánchez, E.I.; Wolfenstein-Todel, C.; Calvete, J.J. Isolation of two novel mannanand L-fucose-binding lectins from the green alga Enteromorpha prolifera: Biochemical characterization of EPL-2. Arch. Biochem. Biophys. 2003, 415, 245-250. [CrossRef]

44. Boyd, M.R.; Gustafson, K.R.; McMahon, J.B.; Shoemaker, R.H.; O’Keefe, B.R.; Mori, T.; Gulakowski, R.J.; $\mathrm{Wu}$, L.; Rivera, M.I.; Laurencot, C.M.; et al. Discovery of cyanovirin-N, a novel human immunodeficiency virus-inactivating protein that binds viral surface envelope glycoprotein gp120: Potential applications to microbicide development. Antimicrob. Agents Chemother. 1997, 41, 1521-1530. [CrossRef] [PubMed]

45. Chiba, H.; Inokoshi, J.; Okamoto, M.; Matsuzaki, K.; Iwama, M.; Mizumoto, K.; Tanaka, H.; Oheda, M.; Fujita, K.; Nakashima, H.; et al. Actinohivin, a novel anti-HIV protein from an actinomycete that inhibits syncytium formation: Isolation, characterization, and biological activities. Biochem. Biophys. Res. Commun. 2001, 282, 595-601. [CrossRef] [PubMed]

46. Huskens, D.; Schols, D. Algal lectins as potential HIV microbicide candidates. Mar. Drugs 2012, 10, $1476-1497$. [CrossRef] [PubMed]

47. Bewley, C.A.; Gustafson, K.R.; Boyd, M.R.; Covell, D.G.; Bax, A.; Clore, G.M.; Gronenborn, A.M. Solution structure of cyanovirin-N, a potent HIV-inactivating protein. Nat. Struct. Biol. 1998, 5, 571-578. [CrossRef] [PubMed]

48. Tanaka, H.; Chiba, H.; Inokoshi, J.; Kuno, A.; Sugai, T.; Takahashi, A.; Ito, Y.; Tsunoda, M.; Suzuki, K.; Takénaka, A.; et al. Mechanism by which the lectin actinohivin blocks HIV infection of target cells. Proc. Natl. Acad. Sci. USA 2009, 106, 15633-15638. [CrossRef] [PubMed]

49. Botos, I.; O'Keefe, B.R.; Shenoy, S.R.; Cartner, L.K.; Ratner, D.M.; Seeberger, P.H.; Boyd, M.R.; Wlodawer, A. Structures of the complexes of a potent anti-HIV protein cyanovirin-N and high mannose oligosaccharides. J. Biol. Chem. 2002, 277, 34336-34342. [CrossRef]

50. Zhang, F.; Hoque, M.M.; Jiang, J.; Suzuki, K.; Tsunoda, M.; Takeda, Y.; Ito, Y.; Kawai, G.; Tanaka, H.; Takenaka, A. The characteristic structure of anti-HIV actinohivin in complex with three HMTG D1 chains of HIV-gp120. Chembiochem 2014, 15, 2766-2773. [CrossRef]

51. Zlólkowska, N.E.; O’Keefe, B.R.; Mori, T.; Zhu, C.; Giomarelli, B.; Vojdani, F.; Palmer, K.E.; McMahon, J.B.; Wlodawer, A. Domain-swapped structure of the potent antiviral protein griffithsin and its mode of carbohydrate binding. Structure 2006, 14, 1127-1135. [CrossRef]

52. Zlólkowska, N.E.; Shenoy, S.R.; O'Keefe, B.R.; Wlodawer, A. Crystallographic studies of the complexes of antiviral protein griffithsin with glucose and N-acetylglucosamine. Protein Sci. 2007, 16, 1485-1489. [CrossRef] [PubMed]

53. Zlólkowska, N.E.; Shenoy, S.R.; O’Keefe, B.R.; McMahon, J.B.; Palmer, K.E.; Dwek, R.A.; Wormald, M.R.; Wlodawer, A. Crystallographic, thermodynamic, and molecular modeling studies of the mode of binding of oligosaccharides to the potent antiviral protein griffithsin. Proteins 2007, 67, 661-670. [CrossRef] [PubMed]

54. Moulaei, T.; Shenoy, S.R.; Giomarelli, B.; Thomas, C.; McMahon, J.B.; Dauter, Z.; O’Keefe, B.R.; Wlodawer, A. Monomerization of viral entry inhibitor griffithsin elucidates the relationship between multivalent binding to carbohydrates and anti-HIV activity. Structure 2010, 18, 1104-1115. [CrossRef] [PubMed]

55. Kim, J.I.; Moore, C.E.; Archibald, J.M.; Bhattacharya, D.; Yi, G.; Yoon, H.S.; Shon, W. Evolutionary dynamics of cryptophyte plastid genomes. Genome Biol. Evol. 2017, 9, 1859-1872. [CrossRef] [PubMed]

56. Brawley, S.H.; Blouin, N.A.; Ficko-Blean, E.; Wheeler, G.L.; Lohr, M.; Goodson, H.V.; Jenkins, J.W.; Blaby-Haas, C.E.; Helliwell, K.E.; Chan, C.X.; et al. Insights into the red algae and eukaryotic evolution from the genome of Porphyra umbilicalis (Bangiophyceae, Rhodophyta). Proc. Natl. Acad. Sci. USA 2017, 114, E6361-E6370. [CrossRef] [PubMed] 
57. Rahman, F.; Hassan, M.; Rosli, R.; Almousally, I.; Hanano, A.; Murphy, D.J. Evolutionary and genomic analysis of the caleosin/peroxygenase (CLO/PXG) gene/protein families in the Viridiplantae. PLoS ONE 2018, 19, 976. [CrossRef]

58. Cavalier-Smith, T. Kingdom Chromista and its eightphyla: A new synthesis emphasising periplastid protein targeting, cytoskeletal and periplastid evolution, and ancient divergences. Protoplasma 2018, 255, 297-357. [CrossRef] [PubMed]

59. Stewart-Jones, G.B.; Soto, C.; Lemmin, T.; Chuang, G.Y.; Druz, A.; Kong, R.; Thomas, P.V.; Wagh, K.; Zhou, T.; Behrens, A.J.; et al. Trimeric HIV-structures define glycan shields from clades A, B, and G. Cell 2016, 165, 813-826. [CrossRef]

60. Huang, X.; Jin, W.; Griffin, G.E.; Shattock, R.J.; Hu, Q. Removal of two high-mannose N-linked glycans on gp120 renders human immunodeficiency virus 1 largely resistant to the carbohydrate-binding agent griffithsin. J. Gen. Virol. 2011, 92, 2367-2373. [CrossRef]

61. Micevicz, E.D.; Cole, A.L.; Jung, C.L.; Luong, H.; Phillips, M.L.; Pratikhya, P.; Sharma, S.; Waring, A.J.; Cole, A.M.; Ruchala, P. Grifonin-I: A small HIV-1 entry inhibitor derived from the algal lectin, griffithsin. PLoS ONE 2010, 5, e14360. [CrossRef]

62. Emau, P.; Tina, B.; O’Keefe, B.K.; Mori, T.; McMahon, J.B.; Palmer, K.E.; Jiang, Y.; Bekele, G.; Tsai, C.C. Griffithsin, a potent HIV entry inhibitor, is an excellent candidate for anti-HIV microbicide. J. Med. Primatol. 2007, 36, 244-253. [CrossRef] [PubMed]

63. O'Keefe, B.R.; Vojdani, F.; Buffa, V.; Shattock, R.J.; Montefiori, D.C.; Bakke, J.; Mirsalis, J.; d'Andrea, A.L.; Hume, S.D.; Bratcher, B.; et al. Scaleable manufacture of HIV-1 entry inhibitor griffithsin and validation of its safety and efficacy as a topical microbicide component. Proc. Natl. Acad. Sci. USA 2009, 106, 6099-6104. [CrossRef] [PubMed]

64. Alexandre, K.B.; Gray, E.S.; Lambson, B.E.; Moore, P.L.; Choge, I.A.; Mlisana, K.; Karim, S.S.; McMahon, J.; O'Keefe, B.; Chikwamba, R.; et al. Mannose-rich glycosylation patterns on HIV-1 subtype C gp120 and sensitivity to the lectins, griffithsin, cyanovirin-N and scytovirin. Virology 2010, 402, 187-196. [CrossRef] [PubMed]

65. Alexandre, K.B.; Gray, E.S.; Pantophlet, R.; Moore, P.L.; McMahon, J.B.; O’Keefe, B.R.; Chikwamba, R.; Morris, L. Binding of the mannose-specific lectin, griffithsin, to HIV-1 gp120 exposes the CD4-binding site. J. Virol. 2011, 85, 9039-9050. [CrossRef] [PubMed]

66. Alexandre, K.B.; Gray, E.S.; Mufhandu, H.; McMahon, J.B.; Chakauya, E.; O'Keefe, B.R.; Chikwamba, R.; Morris, L. The lectins griffithsin, cyanovirin-N and scytovirin inhibit HIV-1 binding to the DC-SIGN receptor and transfer to CD4(+) cells. Virology 2012, 423, 175-186. [CrossRef] [PubMed]

67. Férir, G.; Palmer, K.E.; Schols, D. Synergistic activity profile of griffithsin in combination with tenofovir, maraviroc and enfuvirtide against HIV-1 clade C. Virology 2011, 417, 253-258. [CrossRef] [PubMed]

68. Kouokam, J.C.; Huskens, D.; Schols, D.; Johannemann, A.; Riedell, S.K.; Walter, W.; Walker, J.M.; Matoba, N.; O'Keefe, B.R.; Palmer, K.E. Investigation of griffithsin's interactions with human cells confirms its outstanding safety and efficacy profile as a microbicide candidate. PLoS ONE 2011, 6, e22635. [CrossRef] [PubMed]

69. Xue, J.; Gao, Y.; Hoorelbeke, B.; Kagiampakis, I.; Zhao, B.; Demeler, B.; Balzarini, J.; Liwang, P.J. The role of individual carbohydrate-binding sites in the function of the potent anti-HIV lectin griffithsin. Mol. Pharm. 2012, 9, 2613-2625. [CrossRef] [PubMed]

70. Hoorelbeke, B.; Xue, J.; Liwang, P.J.; Balzarini, J. Role of the carbohydrate-binding sites of griffithsin in the prevention of DC-SIGN-mediated capture and transmission of HIV-1. PLoS ONE 2013, 8, e64132. [CrossRef]

71. Nixon, B.; Stefanidou, M.; Mesquita, P.M.; Fakioglu, E.; Segarra, T.; Rohan, L.; Halford, W.; Palmer, K.E.; Herold, B.C. Griffithsin protects mice from genital herpes by preventing cell-to-cell spread. J. Virol. 2013, 87, 6257-6269. [CrossRef]

72. Xue, J.; Hoorelbeke, B.; Kagiampakis, I.; Demeler, B.; Balzarini, J.; Liwang, P.J. The griffithsin dimer is required for high-potency inhibition of HIV-1: Evidence for manipulation of the structure of gp120 as part of the griffithsin dimer mechanism. Antimicrob. Agents Chemother. 2013, 57, 3976-3989. [CrossRef] [PubMed]

73. Barton, C.; Kouokam, J.C.; Lasnik, A.B.; Foreman, O.; Cambon, A.; Brock, G.; Montefiori, D.C.; Vojdani, F.; McCormick, A.A.; O'Keefe, B.R.; et al. Activity of and effect of subcutaneous treatment with the broad-spectrum antiviral lectin griffithsin in two laboratory rodent models. Antimicrob. Agents Chemother. 2014, 58, 120-127. [CrossRef] [PubMed] 
74. Moulaei, T.; Alexandre, K.B.; Shenoy, S.R.; Meyerson, J.R.; Krumpe, L.R.; Constantine, B.; Wilson, J.; Buckheit, R.W., Jr.; McMahon, J.B.; Subramaniam, S.; et al. Griffithsin tandemers: Flexible and potent lectin inhibitors of the human immunodeficiency virus. Retrovirology 2015, 12, 6. [CrossRef] [PubMed]

75. Barton, C.; Kouokam, J.C.; Hurst, I.; Palmer, K.E. Pharmacokinetics of the antiviral lectin griffithsin administered by different routes indicates multiple potential uses. Viruses 2016, 8, 331. [CrossRef] [PubMed]

76. Kouokam, J.C.; Lasnik, A.B.; Palmer, K.E. Studies in a murine model confirm the safety of griffithsin and advocate its further development as a microbicide targeting HIV-1 and other enveloped viruses. Viruses 2016, 8, 311. [CrossRef] [PubMed]

77. Vuong, H.R.; Tyo, K.M.; Steinbach-Rankins, J.M. Fabrication and characterization of griffithsin-modified fiber scaffolds for prevention of sexually transmitted infections. J. Vis. Exp. 2017, 128, e56492. [CrossRef] [PubMed]

78. Lal, M.; Lai, M.; Ugaonkar, S.; Wesenberg, A.; Kízima, L.; Rodriguez, A.; Levendosky, K.; Mizenina, O.; Fernández-Romero, J.; Zydowsky, T. Development of a vaginal fast-dissolving insert combining griffithsin and carrageenan for potential use against sexually transmitted infections. J. Pharm. Sci. 2018, 107, 2601-2610. [CrossRef] [PubMed]

79. Yang, H.; Li, J.; Patel, S.K.; Palmer, K.E.; Devlin, B.; Rohan, L.C. Design of poly(lactic-co-glycolic acid) (PLGA) nanoparticles for vaginal co-delivery of griffithsin and dapivirin and their synergistic effect for HIV prophylaxis. Pharmaceutics 2019, 11, 184. [CrossRef]

80. Hirahyama, M.; Shibata, H.; Imamura, K.; Sakaguchi, T.; Hori, K. High-mannose specific lectin and its recombinants from a carrageenophyta Kappaphycus alvarezii represent a potent anti-HIV activity through high-affinity binding to the viral envelope glycoprotein gp120. Mar. Biotechnol. 2016, 18, 448. [CrossRef]

81. Meuleman, P.; Albecka, A.; Belouzard, S.; Vercauteren, K.; Verhoye, L.; Wychowski, C.; Leroux-Roels, G.; Palmer, K.E.; Dubuisson, J. Griffithsin has antiviral activity against hepatitis C virus. Antimicrob. Agents Chemother. 2011, 55, 5159-5167. [CrossRef]

82. Takebe, Y.; Saucedo, C.J.; Lund, G.; Uenishi, R.; Hase, S.; Tsuchiura, T.; Kneteman, N.; Ramessar, K.; Tyrrell, D.L.; Shirakura, M.; et al. Antiviral lectins from red and blue-green algae show potent in vitro and in vivo activity against hepatitis C virus. PLoS ONE 2013, 8, e64449. [CrossRef] [PubMed]

83. Levendosky, K.; Mizenina, O.; Martinelli, E.; Jean-Pierre, N.; Kizima, L.; Rodríguez, A.; Kleinbeck, K.; Bonnaire, T.; Robbiani, M.; Zydowsky, T.M.; et al. Griffithsin and carrageenan combination to target Herpes simplex virus 2 and human papillomavirus. Antimicrob. Agents Chemother. 2015, 59, 7290-7298. [CrossRef] [PubMed]

84. O'Keefe, B.R.; Giomarelli, B.; Barnard, D.L.; Shenoy, S.R.; Chan, P.K.; McMahon, J.B.; Palmer, K.E.; Barnett, B.W.; Meyerholz, D.K.; Vohlford-lenane, C.L.; et al. Broad-spectrum in vitro activity and in vivo efficacy of the antiviral protein griffithsin against emerging viruses of the family coronaviridae. J. Virol. 2010, 84, 2511-2521. [CrossRef] [PubMed]

85. Sato, Y.; Morimoto, K.; Kubo, T.; Sakaguchi, T.; Nishizono, A.; Hirayama, M.; Hori, K. Entry inhibition of influenza viruses with high mannose binding lectin ESA-2 from the red alga Eucheuma serra through the recognition of viral hemagglutinin. Mar. Drugs 2015, 13, 3454-3465. [CrossRef] [PubMed]

86. Shahzad-ul-Huassan, S.; Gustchina, E.; Ghirlando, R.; Clore, G.M.; Bewley, C.A. Solution structure of the monovalent lectin microvirin in complex with Man $\alpha(1-2)$ Man provides a basis for anti-HIV activity with low toxicity. J. Biol. Chem. 2011, 286, 20788-20796. [CrossRef]

87. Shiomi, K.; Kamiya, H.; Shimizu, Y. Purification and characterization of an agglutinin in the red alga Agardhiella tenera. Biochim. Biophys. Acta 1979, 576, 118-127. [CrossRef]

88. Pinto, V.P.; Debray, H.; Dus, D.; Teixeira, E.H.; de Oliveira, T.M.; Carneiro, V.A.; Teixeira, A.H.; Filho, G.C.; Nagano, C.S.; Nascimento, K.S.; et al. Lectins from the red marine algal species Bryothamnion seaforthii and Bryothamnion triquetrum as tools to differentiate human colon carcinoma cells. Adv. Pharmacol. Sci. 2009, $2009,862162$.

89. Conrado, F.M.; Furtado, L.E.T.A.; Teixeira, A.H.; Coutinho, N.L.P.; Sampaio, A.H.; Cavada, B.S.; Bezerra, M.M.; Silva, A.A.R.; Barbosa, F.C.B.; Chaves, H.V.; et al. Erythrina velutina and Bryothamnion seaforthii lectins binding to proteins of primary central nervous system tumors. J. Cancer Res. Exp. Oncol. 2012, 4, 21-26. [CrossRef]

90. Sugahara, T.; Ohama, Y.; Fukuda, A.; Hayashi, M.; Kawakubo, A.; Kato, K. The cytotoxic effect of Eucheuma serrata agglutinin (ESA) on cancer cells and its application to molecular probe for drug delivery system using lipid vesicles. Cytotechnology 2001, 36, 93-99. [CrossRef] 
91. Fukuda, Y.; Sugahara, T.; Ueno, M.; Fukuta, Y.; Ochi, Y.; Akiyama, K.; Miyazaki, T.; Masuda, S.; Kawakubo, A.; Kato, K. The anti-tumor effect of Eucheuma serra agglutinin on colon cancer cells in vitro and in vivo. Anticancer Drugs 2006, 17, 943-947. [CrossRef]

92. Omokawa, Y.; Miyazaki, T.; Walde, P.; Akiyama, K.; Sugahara, T.; Masuda, S.; Inada, A.; Ohnishi, Y.; Saeki, T.; Kato, K. In vitro and in vivo anti-tumor effects of novel Span 80 vesicles containing immobilized Eucheuma serra agglutinin. Int. J. Pharm. 2010, 389, 157-167. [CrossRef]

93. Hayashi, K.; Walde, P.; Miyazaki, T.; Sakayama, K.; Nakamura, A.; Kameda, K.; Masuda, S.; Umakoshi, H.; Kato, K. Active targeting to osteosarcoma cells and apoptotic cell death induction by the novel lectin Eucheuma serra agglutinin isolated from a marine red alga. J. Drug Deliv. 2012, 2012, 842785. [CrossRef] [PubMed]

94. Liao, W.R.; Lin, J.Y.; Shieh, W.Y.; Jeng, W.L.; Huang, R. Antibiotic activity of lectins from marine algae against marine vibrios. J. Ind. Microbiol. Biotechnol. 2003, 30, 433-439. [CrossRef] [PubMed]

95. Holanda, M.L.; Melo, V.M.; Silva, L.M.; Amorim, R.C.; Pereira, M.G.; Benevides, N.M. Differential activity of a lectin from Solieria filiformis against human pathogenic bacteria. Braz. J. Med. Biol. Res. 2005, 38, 769-773. [CrossRef] [PubMed]

96. Abreu, T.M.; Ribeiro, N.A.; Chaves, H.V.; Jorge, R.J.; Bezerra, M.M.; Monteiro, H.S.; Vasconcelos, I.M.; Mota, E.F.; Benevides, N.M. Antinociceptive and anti-inflammatory activities of the lectin from marine alga Solieria filiformis. Planta Med. 2016, 82, 596-605. [CrossRef] [PubMed]

97. Abreu, T.M.; Monteiro, V.S.; Martins, A.B.S.; Teles, F.B.; da Conceição Rivanor, R.L.; Mota, E.F.; Macedo, D.S.; de Vasconcelos, S.M.M.; Júnior, J.E.R.H.; Benevides, N.M.B. Involvement of the dopaminergic system in the antidepressant-like effect of the lectin isolated from the red marine alga Solieria filiformis in mice. Int. J. Biol. Macromol. 2018, 111, 534-541. [CrossRef] [PubMed]

98. Do Nascimento-Neto, L.G.; Carneiro, R.F.; da Silva, S.R.; da Silva, B.R.; Vassiliepe Sousa Arruda, F.; Carneiro, V.A.; do Nascimento, K.S.; Saker-Sampaio, S.; da Silva, V.A., Jr.; Porto, A.L.; et al. Characterization of isoforms of the lectin isolated from the red algae Bryothamnion seaforthii and its pro-healing effect. Mar. Drugs 2012, 10, 1936-1954. [CrossRef] [PubMed]

99. Thompson, J.D.; Gibson, T.J.; Plewniak, F.; Jeanmougin, F.; Higgins, D.G. The CLUSTAL-X windows interface: Flexible strategies for multiple sequence alignment aided by quality analysis tool. Nucleic Acids Res. 1997, 15, 4876-4882. [CrossRef]

100. Gaboriaud, C.; Bissery, V.; Benchetrit, T.; Mornon, J.P. Hydrophobic cluster analysis: An efficient new way to compare and analyse amino acid sequences. FEBS Lett. 1987, 224, 149-155. [CrossRef]

101. Page, R.D. TreeView: An application to display phylogenetic trees on personal computers. Comput. Appl. Biosci. 1996, 12, 357-358.

102. Krieger, E.; Koraimann, G.; Vriend, G. Increasing the precision of comparative models with YASARA NOVA-A self-parametrizing force field. Proteins 2002, 47, 393-402. [CrossRef] [PubMed]

103. Laskowski, R.A.; MacArthur, M.W.; Moss, D.S.; Thornton, J.M. PROCHECK: A program to check the stereochemistry of protein structures. J. Appl. Crystallogr. 1993, 126, 283-291. [CrossRef]

104. Melo, F.; Feytmans, E. Assessing protein structures with a non-local atomic interaction energy. J. Mol. Biol. 1998, 277, 1141-1152. [CrossRef] [PubMed]

105. Benkert, P.; Biasini, M.; Schwede, T. Toward the estimation of the absolute quality of individual protein structure models. Bioinformatics 2011, 27, 343-350. [CrossRef] [PubMed]

106. Arnold, K.; Bordoli, L.; Kopp, J.; Schwede, T. The SWISS-MODEL workspace: A web-based environment for protein structure homology modelling. Bioinformatics 2006, 22, 195-201. [CrossRef] [PubMed]

107. Kirschner, K.N.; Yongye, A.B.; Tschampel, S.M.; Daniels, C.R.; Foley, B.L.; Woods, R.J.J. GLYCAM06: A generalizable biomolecular force field. Carbohydrates. Comput. Chem. 2008, 29, 622-655. [CrossRef]

108. Frank, M.; Schloissnig, S. Bioinformaticsand and molecular modeling in glycobiology. Cell. Mol. Life Sci. 2010, 67, 2749-2772. [CrossRef]

109. Bohne, A.; Lang, E.; von der Lieth, C.W. SWEET-WWW-based rapid 3D construction of oligo-and polysaccharides. Bioinformatics 1999, 15, 767-768. [CrossRef]

110. Trott, O.; Olson, A.J. AutoDock VINA: Improving the speed and accuracy of docking with a new scoring function, efficient optimization and multithreading. J. Comput. Chem. 2010, 31, 455-461. [CrossRef]

111. Grosdidier, A.; Zoete, V.; Michielin, O. SwissDock, a protein-small molecule docking web service based on EADock DSS. Nucleic Acids Res. 2011, 39, W270-W277. [CrossRef] 
112. Grosdidier, A.; Zoete, V.; Michielin, O. Fast docking using the CHARMM force field with EADock DSS. J. Comput. Chem. 2011, 32, 2149-2159. [CrossRef] [PubMed]

113. Pettersen, E.F.; Goddard, T.D.; Huang, C.C.; Couch, G.S.; Greenblatt, D.M.; Meng, E.C.; Ferrin, T.E. UCSF Chimera-A visualization system for exploratory research and analysis. J. Comput. Chem. 2004, 25, 1605-1612. [CrossRef] [PubMed]

114. Nagano, C.S.; Debray, H.; Nascimento, K.S.; Pinto, V.P.; Cavada, B.S.; Saker-Sampaio, S.; Farias, W.R.; Sampaio, A.H.; Calvete, J.J. HCA and HML isolated from the red marine algae Hypnea cervicormis and Hypnea musciformis define a novel lectin family. Protein Sci. 2005, 14, 2167-2178. [CrossRef] [PubMed]

115. Férir, G.; Huskens, D.; Noppen, S.; Koharudin, L.M.; Gronenborn, A.M.; Schols, D. Broad anti-HIV activity of the Oscillatoria agardhii agglutinin homologue lectin family. J. Antimicrob. Chemother. 2014, 69, 2746-2758. [CrossRef]

116. Nuck, R.; Paul, C.; Wieland, B.; Heldrich, C.; Geilen, C.C.; Reutter, W. Comparative study of high mannose-type oligosaccharides in membrane glycoproteins of rat hepatocytes and different rat hepatoma cell lines. Eur. J. Biochem. 1993, 216, 215-221. [CrossRef]

117. Przybylo, M.; Hoja-Lukowicz, D.; Litynska, A.; Laidler, P. Different glycosylation of cadherins from human bladder non-malignant and cancer cell lines. Cancer Cell Int. 2002, 18, 6. [CrossRef]

118. Zhao, Y.; Li, J.; Wang, J.; Xing, Y.; Geng, M. Role of cell surface oligosaccharides of mouse mammary tumor cell lines in cancer metastasis. Indian J. Biochem. Biophys. 2007, 44, 145-151.

119. De Leoz, M.L.; An, H.J.; Krnonewitter, S.; Kim, J.; Beecroft, S.; Vinall, R.; Miyamoto, S.; de Were White, R.; Lam, K.S.; Lebrilla, C. Glycomic approach for potential biomarkers on prostate cancer: Profiling of N-linked glycans in human sera and pRNS cell lines. Dis. Markers 2008, 25, 243-258. [CrossRef]

120. De Leoz, M.M.; Young, L.J.; An, H.J.; Kronewitter, S.R.; Kim, J.; Miyamoto, S.; Borowsky, A.D.; Chew, H.K.; Lebrilla, C.B. High-mannose glycans are elevated during breast cancer progression. Mol. Cell. Proteomics 2011, 10, M110.002717. [CrossRef]

121. Liu, X.; Nie, H.; Zhang, Y.; Yao, Y.; Maitikabili, A.; Qu, Y.; Shi, S.; Chen, C.; Li, Y. Cell surface-specific N-glycan profiling in breast cancer. PLoS ONE 2013, 8, e72704. [CrossRef]

122. Sethi, M.K.; Thaysen-Andersen, M.; Smith, J.T.; Baker, M.S.; Packer, N.H.; Hancock, W.S.; Fanayan, S. Comparative N-glycan profiling of colorectal cancer cell lines reveals unique bisecting GlcNAc and $\alpha$-2,3-linked sialic acid determinants are associated with membrane proteins of the more metastatic/aggressive cell lines. J. Proteome Res. 2014, 13, 277-288. [CrossRef] [PubMed]

123. Kaprio, T.; Satomaa, T.; Heiskanen, A.; Hokke, C.H.; Deelder, A.M.; Mustonen, H.; Hagström, J.; Carpen, O.; Saarinen, J.; Haglund, C. N-glycomic profiling as a tool to separate rectal adenomas from carcinomas. Mol. Cell. Proteomics 2015, 14, 277-288. [CrossRef] [PubMed]

124. Holst, S.; Wuhrer, M.; Rombouts, Y. Glycosylation characteristics of colorectal cancer. Adv. Cancer Res. 2015, 126, 203-256. [PubMed]

125. Park, H.M.; Hwang, M.P.; Kim, Y.W.; Kim, K.J.; Jin, J.M.; Kim, H.Y.; Lee, K.H.; Kim, Y.G. Mass spectrometry-based $\mathrm{N}$-linked glycomic profiling as a means for tracking pancreatic cancer metastasis. Carbohydr. Res. 2015, 413, 5-11. [CrossRef] [PubMed]

126. Chen, H.; Deng, Z.; Huang, C.; Wu, H.; Zhao, X.; Li, Y. Mass spectrometric profiling reveals association of N-glycan patterns with epithelial ovarian cancer progression. Tumour Biol. 2017, 39, 1010428317716249. [CrossRef] [PubMed]

127. Talabnin, K.; Talabnin, C.; Ishihara, M.; Azadi, P. Increased expression of the high-mannose M6N2 and NeuAc3H3N3M3N2F tri-antennary N-glycans in cholangiocarcinoma. Oncol. Lett. 2017, 15, 1030-1036. [CrossRef] [PubMed]

128. Zhang, D.; Xie, Q.; Wang, Q.; Wang, Y.; Miao, J.; Li, L.; Zhang, T.; Cao, X.; Li, Y. Mass spectrometry analysis reveals aberrant N-glycans in colorectal cancer tissues. Glycobiology 2019, 29, 372-384. [CrossRef]

129. Derby, N.; Lal, M.; Aravantinou, M.; Kizima, L.; Barnable, P.; Rodriguez, A.; Lai, M.; Kleinbeck, K.; Lifison, J.D.; Peet, M.M.; et al. Griffithsin carrageenan fast dissolving inserts prevent SHIV HSV2 and HPV infections in vivo. Nat. Commun. 2018, 9, 3881. [CrossRef]

130. Férir, G.; Huskens, D.; Palmer, K.E.; Boudreaux, D.M.; Swanson, M.D.; Markovitz, D.M.; Balzarini, J.; Schols, D. Combinations of griffithsin with other carbohydrate-binding agents demonstrate superior activity against HIV type 1, HIV type 2, and selected carbohydrate-ding agent-resistant HIV type 1 strains. AIDS Res. Hum. Retrovir. 2012, 28, 1513-1523. [CrossRef] 
131. Grooms, T.N.; Vuung, H.R.; Tyo, K.M.; Malik, D.A.; Sims, L.B.; Whittington, C.P.; Palmer, K.E.; Matoba, N.; Steinbach-Rankins, J.M. Griffithsin-modified electrospun fibers as a delivery scaffold to prevent HIV infection. Antimicrob. Agents Chemother. 2016, 60, 6518-6531. [CrossRef]

132. Vamvaka, E.; Farré, G.; Molinos-Albert, L.M.; Evans, A.; Canela-Xandri, A.; Twyman, R.M.; Carrillo, J.; Ordóñez, A.; Shattock, R.J.; O'Keefe, B.R.; et al. Unexpected synergistic HIV neutralization by a triple microbicide produced in rice endosperm. Proc. Natl. Acad. Sci. USA 2018, 115, E7854-E7862. [CrossRef] [PubMed]

(C) 2019 by the authors. Licensee MDPI, Basel, Switzerland. This article is an open access article distributed under the terms and conditions of the Creative Commons Attribution (CC BY) license (http://creativecommons.org/licenses/by/4.0/). 